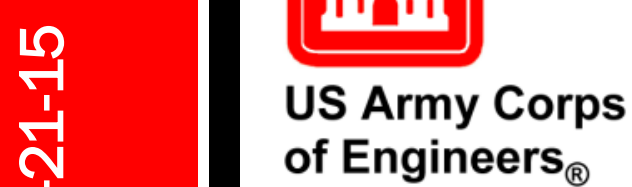

\title{
FERC
}

Engineer Research and

Development Center

\section{Artificial Ground Freezing Using Solar-Powered Thermosyphons}

Anna M. Wagner, Jon B. Maakestad, Edward Yarmak Jr.,

October 2021 and Thomas A. Douglas

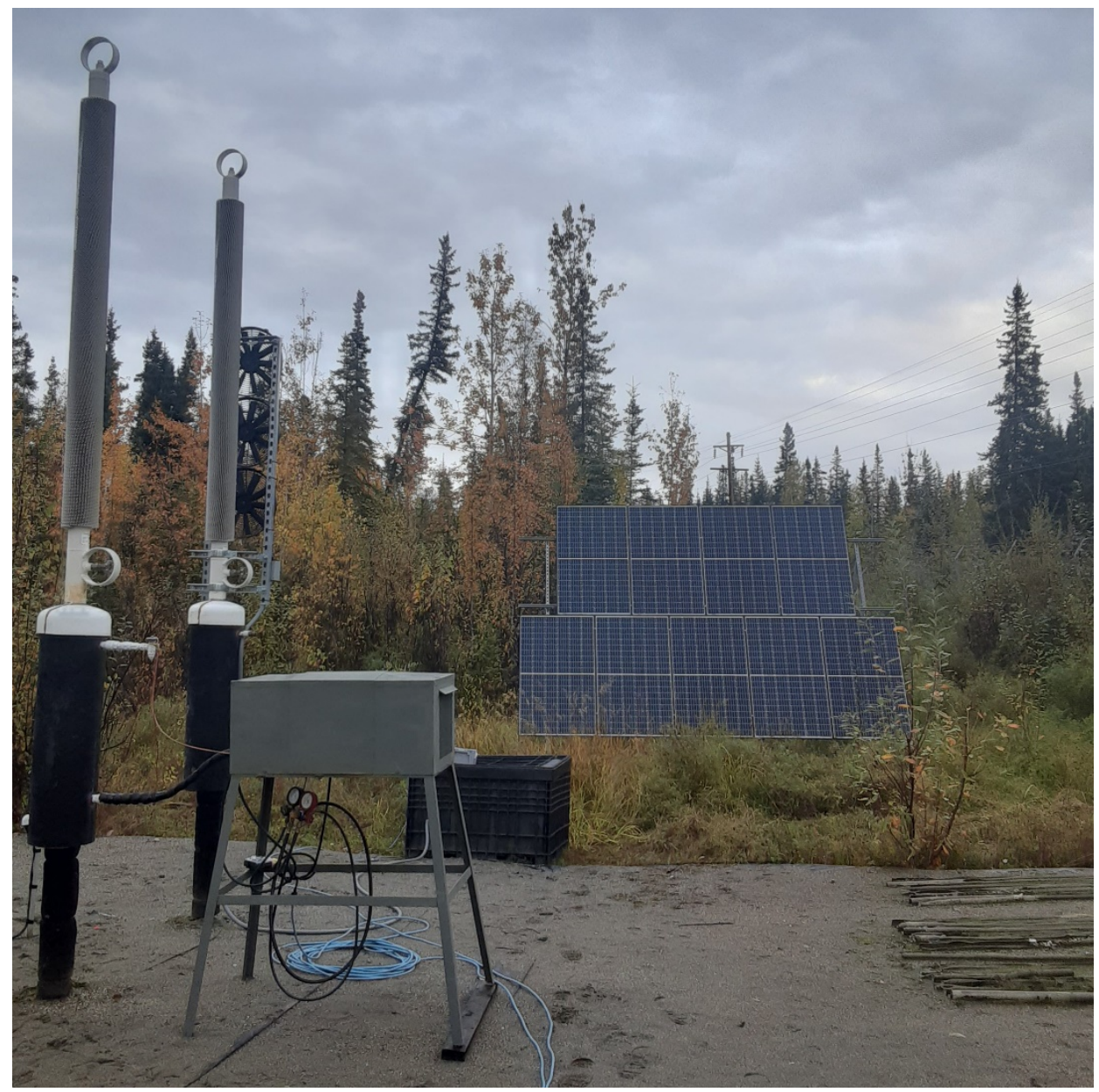


The U.S. Army Engineer Research and Development Center (ERDC) solves the nation's toughest engineering and environmental challenges. ERDC develops innovative solutions in civil and military engineering, geospatial sciences, water resources, and environmental sciences for the Army, the Department of Defense, civilian agencies, and our nation's public good. Find out more at www.erdc.usace.army.mil.

To search for other technical reports published by ERDC, visit the ERDC online library at https://erdclibrary.on.worldcat.org/discovery. 


\section{Artificial Ground Freezing Using Solar-Powered Thermosyphons}

Anna M. Wagner, Jon B. Maakestad, and Thomas A. Douglas

U.S. Army Engineer Research and Development Center (ERDC)

Cold Regions Research and Engineering Laboratory (CRREL)

4070 9th Street

Fort Wainwright, AK 99703

Edward Yarmak, Jr.

Arctic Foundations Inc.

5621 Arctic Boulevard

Anchorage, AK 99518

Final Report

Approved for public release; distribution is unlimited.

Prepared for Headquarters, U.S. Army Corps of Engineers

Washington, DC 20314-1000

Under PE 0603734A, Project T15, "Reliable Distributed Generation in Austere Environments," and PE 0603119A, Project B03, Task SB0321, "Thermosyphons" 


\section{Abstract}

Thermosyphons are an artificial ground-freezing technique that has been used to stabilize permafrost since the 1960s. The largest engineered structure that uses thermosyphons to maintain frozen ground is the Trans Alaska Pipeline, and it has over 124,000 thermosyphons along its approximately $1300 \mathrm{~km}$ route. In passive mode, thermosyphons extract heat from the soil and transfer it to the environment when the air temperature is colder than the ground temperature. This passive technology can promote ground cooling during cold winter months.

To address the growing need for maintaining frozen ground as air temperatures increase, we investigated a solar-powered refrigeration unit that could operate a thermosyphon (nonpassive) during temperatures above freezing. Our tests showed that energy generated from the solar array can operate the refrigeration unit and activate the hybrid thermosyphon to artificially cool the soil when air temperatures are above freezing. This technology can be used to expand the application of thermosyphon technology to freeze ground or maintain permafrost, particularly in locations with limited access to line power.

DISCLAIMER: The contents of this report are not to be used for advertising, publication, or promotional purposes. Citation of trade names does not constitute an official endorsement or approval of the use of such commercial products. All product names and trademarks cited are the property of their respective owners. The findings of this report are not to be construed as an official Department of the Army position unless so designated by other authorized documents.

DESTROY THIS REPORT WHEN NO LONGER NEEDED. DO NOT RETURN IT TO THE ORIGINATOR. 


\section{Contents}

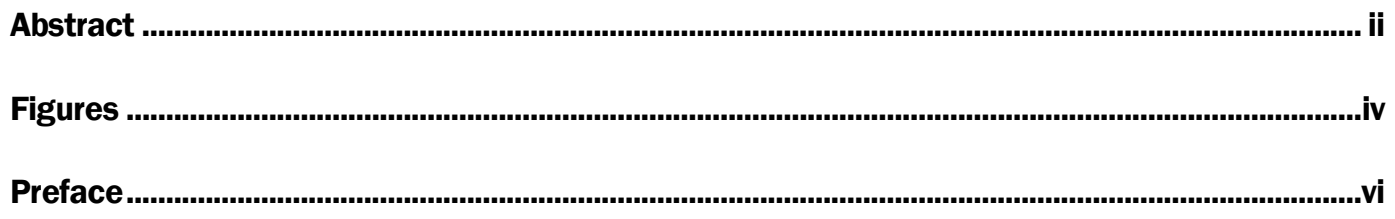

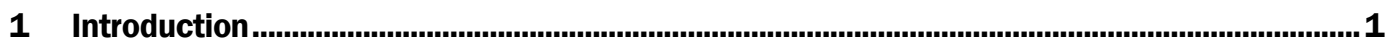

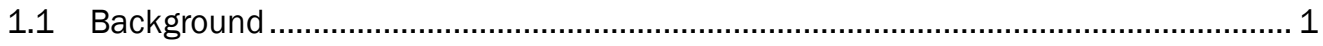

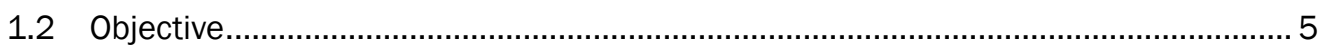

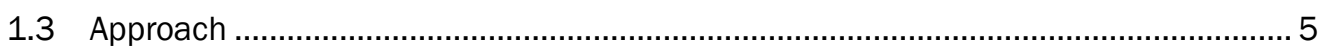

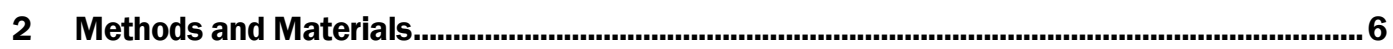

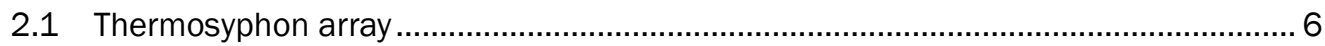

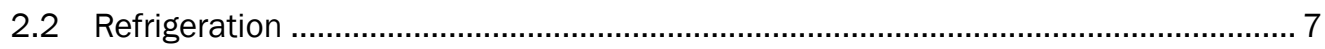

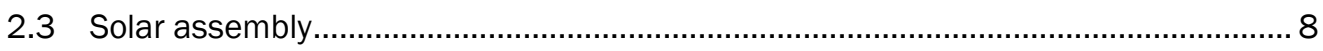

2.4 Temperature monitoring .............................................................................. 10

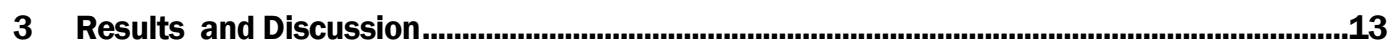

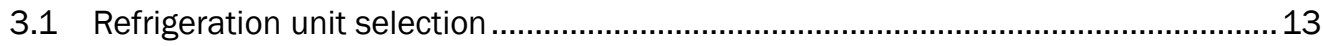

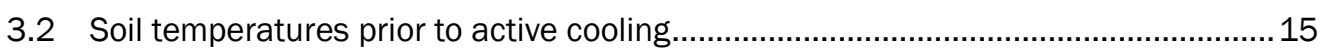

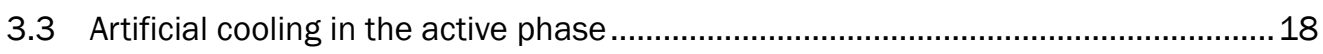

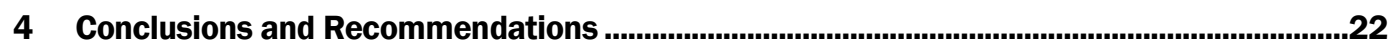

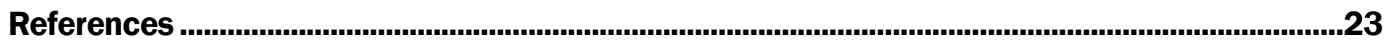

Report Documentation Page ............................................................................................................25 


\section{Figures}

1 Diagram of a passive thermosyphon (from Wagner 2013) ....

2 Mean annual air temperatures (red line) at the Fairbanks International Airport, Alaska. Fitted lines for years 1930-2020 and 1990-2020 are shown in black and blue, respectively

3 In Fairbanks, Alaska, from 1930 to 2015, (a) start thaw date, (b) end thaw date, and $(c)$ thawing season in Fairbanks, Alaska (data from National Weather Service 2017)

$4 \quad$ The thermosyphon system during the 2011-2012 Frozen Barrier Demonstration project with the Bohn BDT0601L6C in operation (Wagner 2013)

5 Solar hybrid thermosyphon layout including test apparatus and groundtemperature-monitoring network. The "T" strings (red $X$ ) show legacy temperature strings, and the "R" strings (green $X$ ) illustrate newly installed temperature strings (see section 2.4). Insulated ground cover consists of a $0.15 \mathrm{~m}$ thick layer of foam board. Distances are in meters................................................ 6

$6 \quad$ Heat removal rates for the selected refrigeration units........................................................ 8

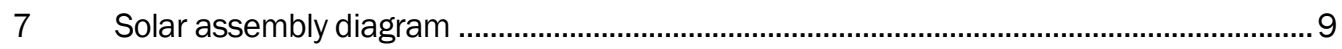

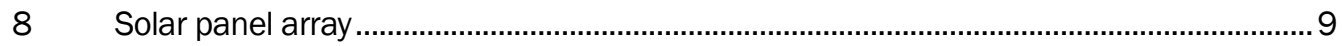

9 Conext ComBox communication and data monitoring system and the battery bank. Installation of thermistor string casings (R1-R3) with a Geoprobe 7822

11 Ground-temperature-monitoring layout. Old and new infrastructure as compared to thermosyphon infrastructure at the test site. At the time of initial installation, the depth to permafrost was $7 \mathrm{~m}$ (see Fig. 12)

12 Temperature-sensor depths. Temperature-monitoring-string numbers and associated sensor depths. The dashed line indicates depth to frozen ground as measured with temperature strings in 2011 (prior to artificial freezing of the site)

13 Soil temperatures during active and passive phases for a control temperature string (top) and a midpoint temperature string between the \#3 and \#4 thermosyphons (bottom) (revised from Wagner 2013). Silt soils are encountered down to depths of at least $10 \mathrm{~m}$. The white field in the lower panel corresponds to missing data due to battery malfunction

14 Estimated ground cooling for different heat removal rates of (a) $290 \mathrm{~W},(b)$ $580 \mathrm{~W},(c) 870 \mathrm{~W}$, and (d) $1160 \mathrm{~W}$ at the Frozen Barrier Demonstration site

Air temperature (5 min averages, black line), solar radiation (5 min averages, blue line), and precipitation (daily, red bars) at the Fairbanks International Airport, Alaska

18 Soil temperatures between thermosyphon \#3 and \#4 at $0.5 \mathrm{~m}$ (top) and $10.0 \mathrm{~m}$ (bottom). Some loss of data occurred due to logger battery failure in winter 2020 
January (left), 1 May (middle), and 1 September (right) 2019. See

temperature-string placement in Fig. 5

20 Soil-temperature curves (6.0 to $11.0 \mathrm{~m}$ ) on 1 January 2020 (before active refrigeration) at control (black line), between thermosyphons \#3 and \#4 (T2 and T3, solid red and blue lines), and between thermosyphons \#5 and \#6 (R2 and R3, dashed red and blue lines).

21 Soil temperatures between thermosyphon \#5 and \#6 at a depth of (a) 2.0 $\mathrm{m}$, (b) $4.0 \mathrm{~m}$, (c) $6.0 \mathrm{~m}$, and (d) $9.2 \mathrm{~m}$ from 15 August to 31 October 2020 and (e) Daily air temperature at the Fairbanks International Airport, Alaska 19

22 Soil temperature at $9.2 \mathrm{~m}$ (R1 temperature string), battery voltage (blue line), PV total power (black line), and load power (red line) for 26 August to 31 October 2020 (top) and 26 August to 4 September 2020 (bottom). Dark gray bars show precipitation (P.), and solar radiation at the Fairbanks International Airport is shown in orange. Light gray fields (bottom) indicate sunrise to sunset. 


\section{Preface}

This study was conducted for U.S. Army Corps of Engineers, Headquarters, under PE 0603734A, Project T15, "Reliable Distributed Generation in Austere Environments.” Dr. Ashok Kumar was the Program Manager, U.S. Army Engineer Research and Development Center, Construction Engineering Research Laboratory (ERDC-CERL). This project was also funded under PE 0603119A, Project BO3, Task SBo321, “Thermosyphons.”

The work was performed by the Biogeochemical Sciences Branch (Mr. Nathan Lamie, Chief) and the Engineering Resources Branch (Dr. Caitlin Callaghan, Chief) of the Research and Engineering Division, ERDC Cold Regions Research and Engineering Laboratory (CRREL). At the time of publication, Dr. George Calfas was Chief of the Research and Engineering Division; and Dr. Douglas Howard was the Technical Director for Cold Regions. The Deputy Director of ERDC-CRREL was Mr. David Ringelberg, and the Director was Dr. Joseph L. Corriveau.

COL Teresa A. Schlosser was Commander of ERDC, and Dr. David W. Pittman was the Director. 


\section{Introduction}

\subsection{Background}

Methods of controlling or altering the thermal regime in frozen ground will continue to be of concern for existing and planned Arctic and sub-Arctic regional infrastructure. In many cold climate regions, preserving permafrost at below freezing temperatures is the safest and most economical means of maintaining infrastructure. Since the 1960s, thermosyphons have been used extensively in Arctic and sub-Arctic locations to create or maintain frozen ground and soil stability below buildings, pipelines, and roadways (e.g., Long 1966; Esch 1996; DenHartog 1988; Haynes and Zarling 1988; Wagner 2014; Wagner et al. 2010; Yarmak and Long 2012; Daggett et al. 2019). Additionally, and more recently, thermosyphons have also successfully contained contaminants at tailings dams in both Canada and Russia (French 2007; Jamieson 2014). These passive heat transfer piles do not require external power sources or control systems to operate when environmental conditions are appropriate. As such, they are both simple and advantageous as a means of protecting the stability of frozen soils with minimal cost and without installing major infrastructure. However, passive thermosyphons are capable of operating only when the heatrejecting section (top, in air) is at a temperature below that of the heat absorbing section (bottom, in ground). For frozen-soil applications, this means thermosyphons operate only when the ambient air temperature is below freezing. This limits the applicability of thermosyphons in "warm" permafrost; and in many locations, climate warming has led to shorter operating hours per year when passive thermosyphons are functional.

Thermosyphons are passive heat-transfer devices that are charged with a pressurized working fluid (see Figure 1). When there is a temperature gradient between the subsurface (evaporator) and the pipe exposed to the air (condenser), the subsurface heat is transferred to the colder and upper part of the thermosyphons, resulting in freezing the ground. Refrigerant in the pipe (typically carbon dioxide or ammonia) is pressurized to a degree such that both liquid and saturated vapor phases are present. Once the upper end (condenser) is at a temperature below the evaporator, condensation of the vapor refrigerant begins to occur on the cooler surface, causing a minor pressure drop and triggering heat absorption and vaporization of liquid-phase refrigerant in the evaporator section. This vapor condenses in 
the cooler condensation section, transferring its latent energy to the condenser and running back down the inner walls of the thermosyphon until it absorbs enough energy to once again become vapor. This process continues as long as the condenser is at a lower temperature than the evaporator (Yarmak and Zottola 2017).

Figure 1. Diagram of a passive thermosyphon (from Wagner 2013).

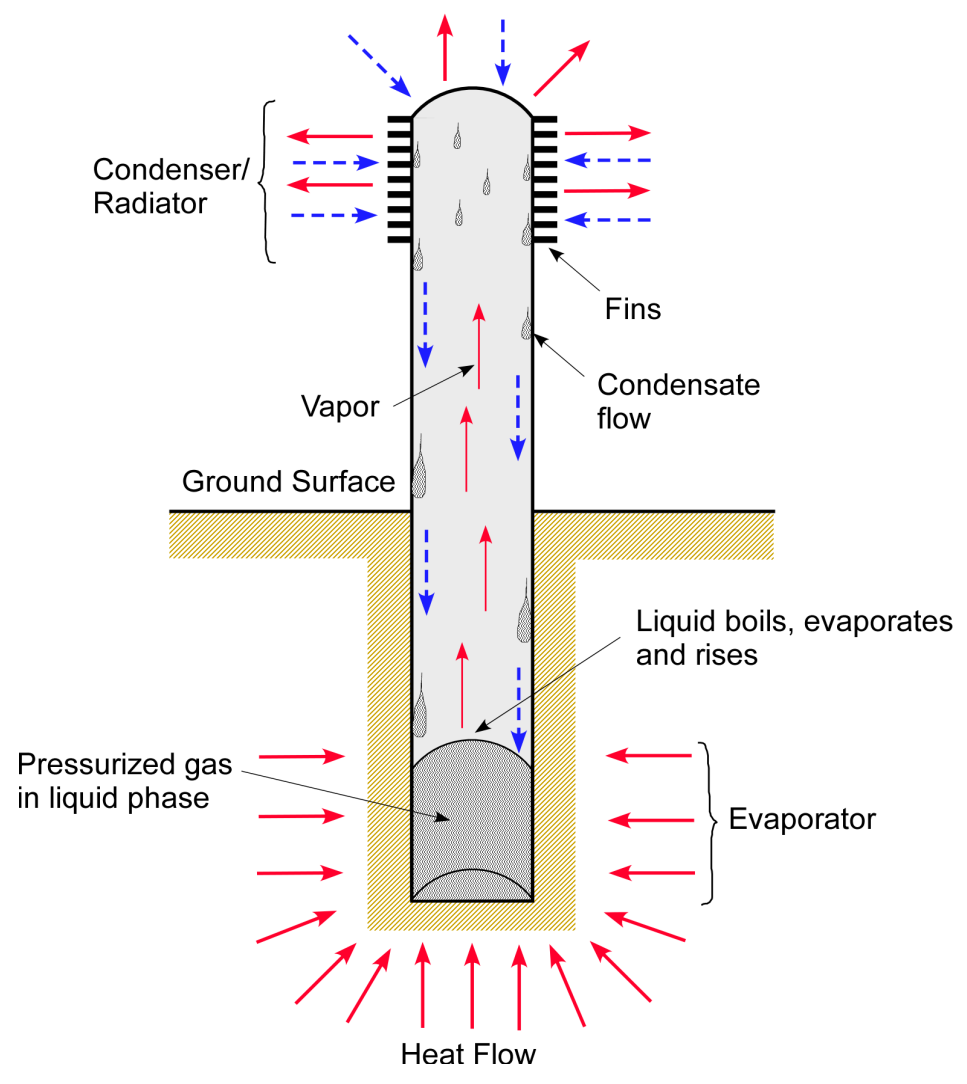

Thermosyphons that operate only when the temperature above ground level is colder than the temperature below ground level are referred to as passive. Passive thermosyphons never utilize external power and only function when the air temperature is below freezing. They are the cheapest to maintain since they have no electrical or moving parts. Active thermosyphons utilize a heat pump to provide a cold sink for the condenser and can be used at any time of the year in any climate or when an immediate freeze-up is needed. These systems use refrigerant to operate regardless of atmospheric conditions. A hybrid system combines passive and active techniques. Hybrid systems function in a passive capacity when ambient temperatures are sufficiently low. If atmospheric conditions are not conducive to passive operation, active refrigeration components can be used to continue thermosyphon operation. 
Currently, active systems require local electrical power to compress and move refrigerant, and this limits where they can be operated. Therefore, for locations with limited access to power, there is a need to develop a selfmaintained system that can function without being connected to a gridbased power source. A promising new thermosyphon design consists of hybrid systems that use solar energy as a power source. These could extend the ground-cooling periods beyond the typical cold winter months when passive systems are most efficient. Solar-powered hybrid systems may also be used to retrofit existing passive thermosyphons to address shifts in cooling requirements due to changing local climate or ground thermal conditions. For example, in Fairbanks, Alaska, the annual mean air temperature is slightly increasing (see Figure 2). For a 90-year temperature record (1930-2020), the annual mean air temperature has ranged between $-5.9^{\circ} \mathrm{C}^{*}$ and $0.4^{\circ} \mathrm{C}$ (1956 and 2019 , respectively). The yearly increasing trend for the last 30 years is twice what it was over the last 90 years $\left(0.045^{\circ} \mathrm{C} /\right.$ year compared to $0.025^{\circ} \mathrm{C} /$ year, blue and black lines in Figure 2).

Figure 2. Mean annual air temperatures (red line) at the Fairbanks International Airport, Alaska. Fitted lines for years 1930-2020 and 1990-2020 are shown in black and blue, respectively.

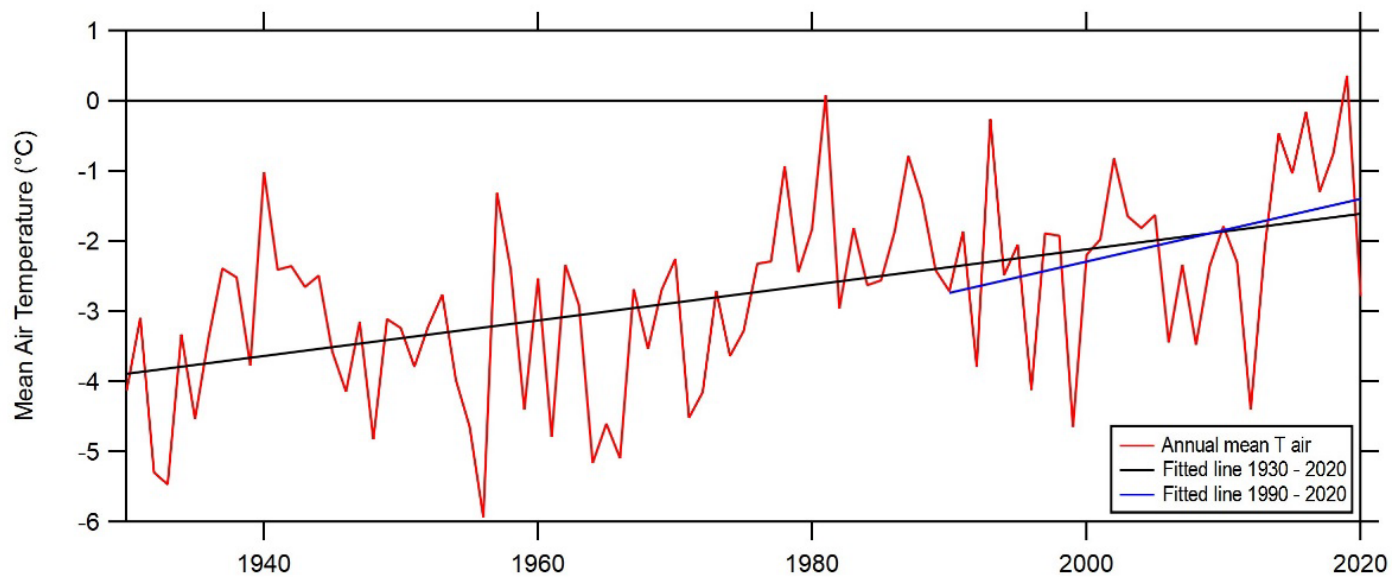

For a temperature record from 1930 to 2015, there is an increasing trend in Fairbanks of a longer thawing season (Figure 3). The trend shows a change in climate where there is a shift to an earlier start of thaw (from 21 May to 13 May) and a delayed end of thaw (from 28 August to 13 September). The

* For a full list of the spelled-out forms of the units of measure used in this document, please refer to U.S. Government Publishing Office Style Manual, 31st ed. (Washington, DC: U.S Government Publishing Office, 2016), 248-252, https://www.govinfo.gov/content/pkg/GPO-STYLEMANUAL-2016/pdf/GPO- 
length of the thawing season is increasing by about 3 days per decade. Lader et al. (2020) also predicted a later onset of snow and earlier snowmelt, meaning that the length of the thawing season would continue to lengthen in future climates.

Figure 3. In Fairbanks, Alaska, from 1930 to 2015, (a) start thaw date, (b) end thaw date, and (c) thawing season in Fairbanks, Alaska (data from National Weather Service 2017).
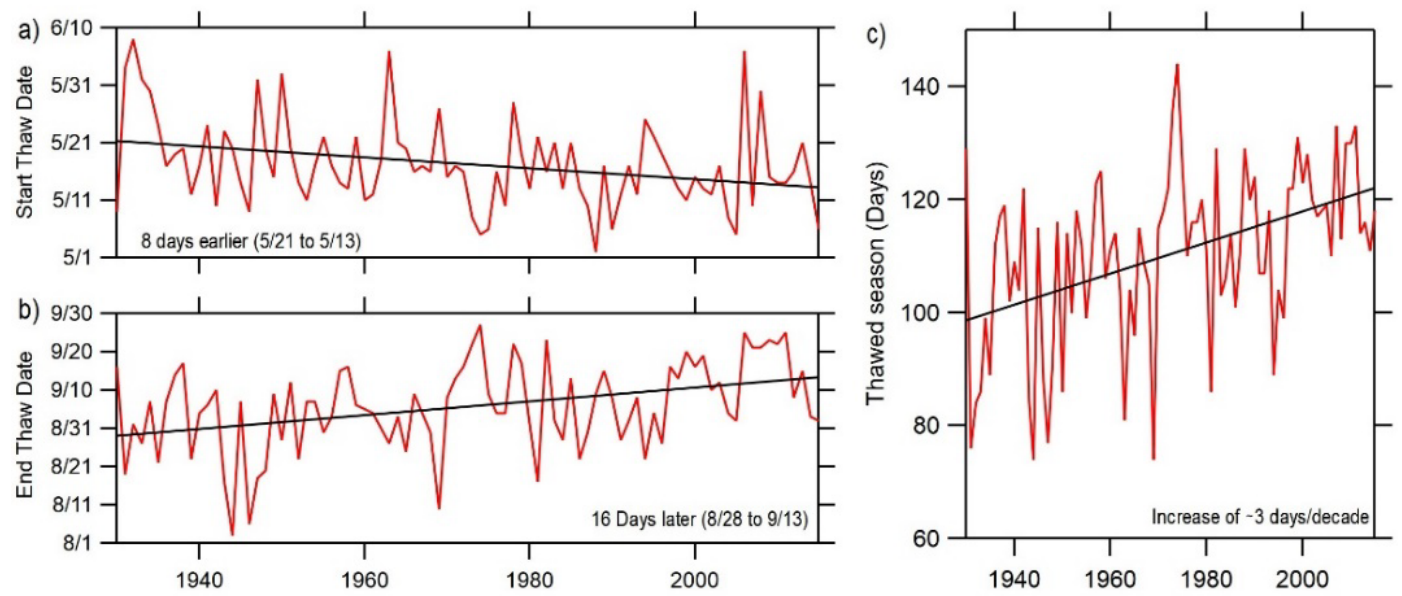

In July 2011, Wagner and Yarmak (2012) constructed a small-scale hybrid thermosyphon testing site at the Farmer's Loop Permafrost Experimental Test Site, Fairbanks, Alaska, as part of a Frozen Barrier Demonstration project. The purpose of that demonstration was to explore the viability of thermosyphons in preventing contamination transport through groundwater by artificially freezing soils. Additionally, it aimed to determine the freezing times to create a frozen barrier using an active thermosyphon system. The test apparatus consisted of six hybrid thermosyphons operable in an active or passive configuration arranged in a line at $1.5 \mathrm{~m}$ spacing (Figure 4). Refrigeration for all six thermosyphons in active operation (connected to line power) was provided by one $4.5 \mathrm{~kW}(6 \mathrm{hp})$ Bohn (Stone Mountain, Georgia, USA) compressor/condenser set. The cooling capacity of that unit was $11.4 \times 10^{6} \mathrm{~kW}$.

The 2012-2013 demonstration used the active phase to freeze the barrier; but once the system was in the passive phase, the ground remained frozen, illustrating that this system could be used to create a frozen wall. However, the question remained whether such a system could operate off-grid using a solar powered refrigeration unit. 
Figure 4. The thermosyphon system during the 2011-2012 Frozen

Barrier Demonstration project with the Bohn BDT0601L6C in operation (Wagner 2013).

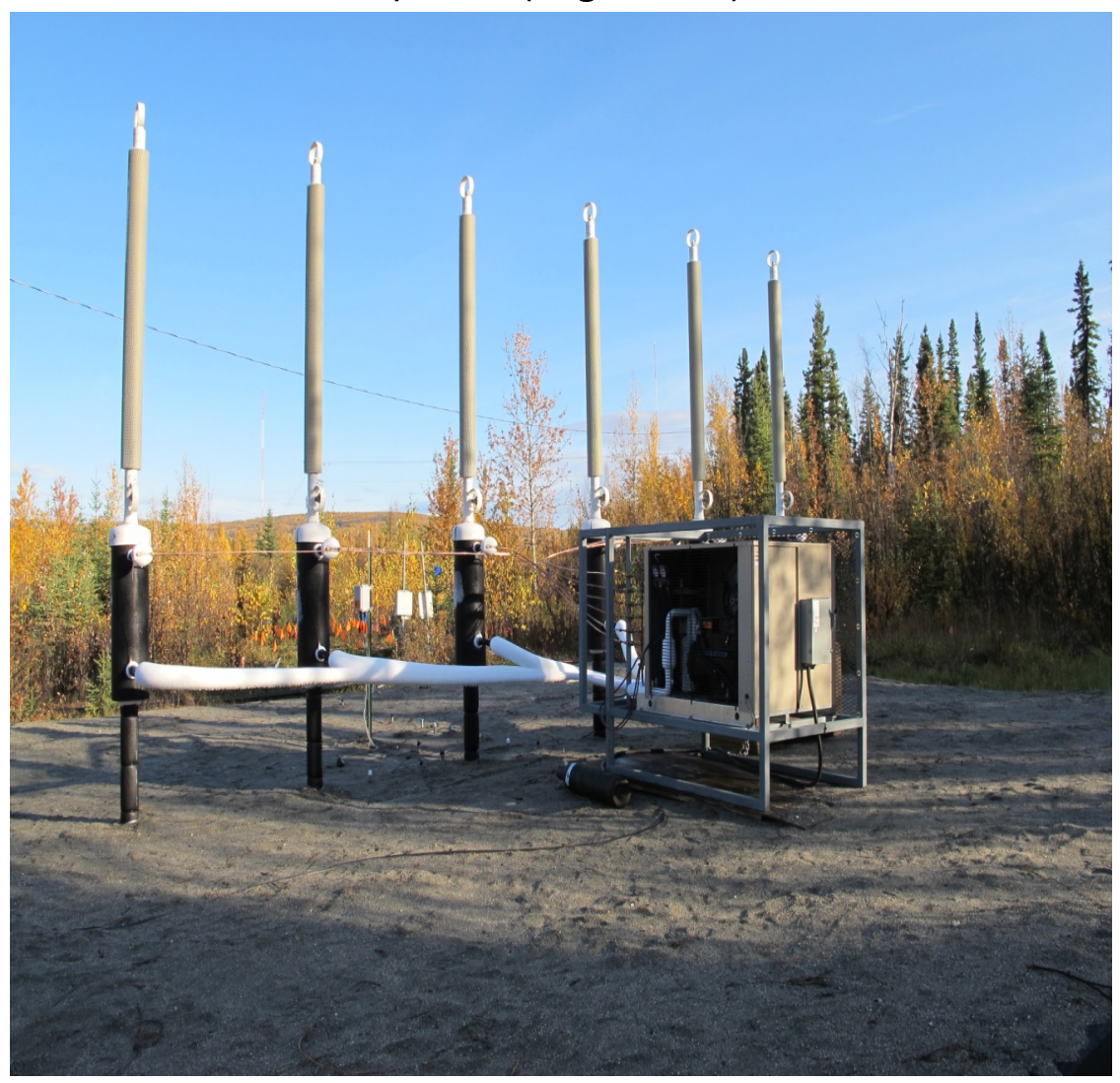

\subsection{Objective}

The objective of this study was to explore the feasibility of operating a vapor compression refrigeration system using a renewable energy source (solar array).

\subsection{Approach}

The six hybrid thermosyphons of the Frozen Barrier Demonstration array at the Farmer's Loop Fairbanks Permafrost Experimental Test Site in Fairbanks, Alaska, have been in passive mode since September 2011, operating, therefore, in the colder months only (Wagner and Yarmak 2012). We connected one of these thermosyphon units to a solar-panel-powered refrigeration unit and compared the power consumption between the two units (powered and nonpowered) to investigate the efficiency of the system. By understanding this, we can determine whether it is feasible to effectively run thermosyphons all summer or to extend the shoulder seasons. 


\section{Methods and Materials}

\subsection{Thermosyphon array}

The Frozen Barrier Demonstration test site is at a disturbed permafrost site that has been used for permafrost infrastructure and science experiments since the 1940s (Douglas et al. 2008). The soils at this site are tan silt near the surface and gray silt at depths below $1.4 \mathrm{~m}$. Because this site had been disturbed before installation of the frozen barrier, the permafrost depth at this site was $7 \mathrm{~m}$ (Wagner 2013). A shallow layer of gravel covered the surface. The thermosyphon array and associated soil-temperature monitoring network formed the infrastructure for the solar hybrid thermosyphon test (Figure 4). The six thermosyphons were originally installed along a line at a distance of $1.5 \mathrm{~m}$ (Figure 5 ) from one another. The length of the evaporators were $12.2 \mathrm{~m}$, and a nonstandard nominal diameter of $63.5 \mathrm{~mm}$ was used for the evaporators (Wagner and Yarmak 2012). This size evaporator was chosen so that during installation, they could fit inside an $82.6 \mathrm{~mm}$ diameter hole excavated with a triple key hollow stem auger. The total condenser fin area was $6.5 \mathrm{~m}^{2}$.

Figure 5. Solar hybrid thermosyphon layout including test apparatus and ground-temperature-monitoring network. The " $T$ " strings (red $X$ ) show legacy temperature strings, and the " $R$ " strings (green $X$ ) illustrate newly installed temperature strings (see section 2.4). Insulated ground cover consists of a $0.15 \mathrm{~m}$ thick layer of foam board. Distances are in meters.

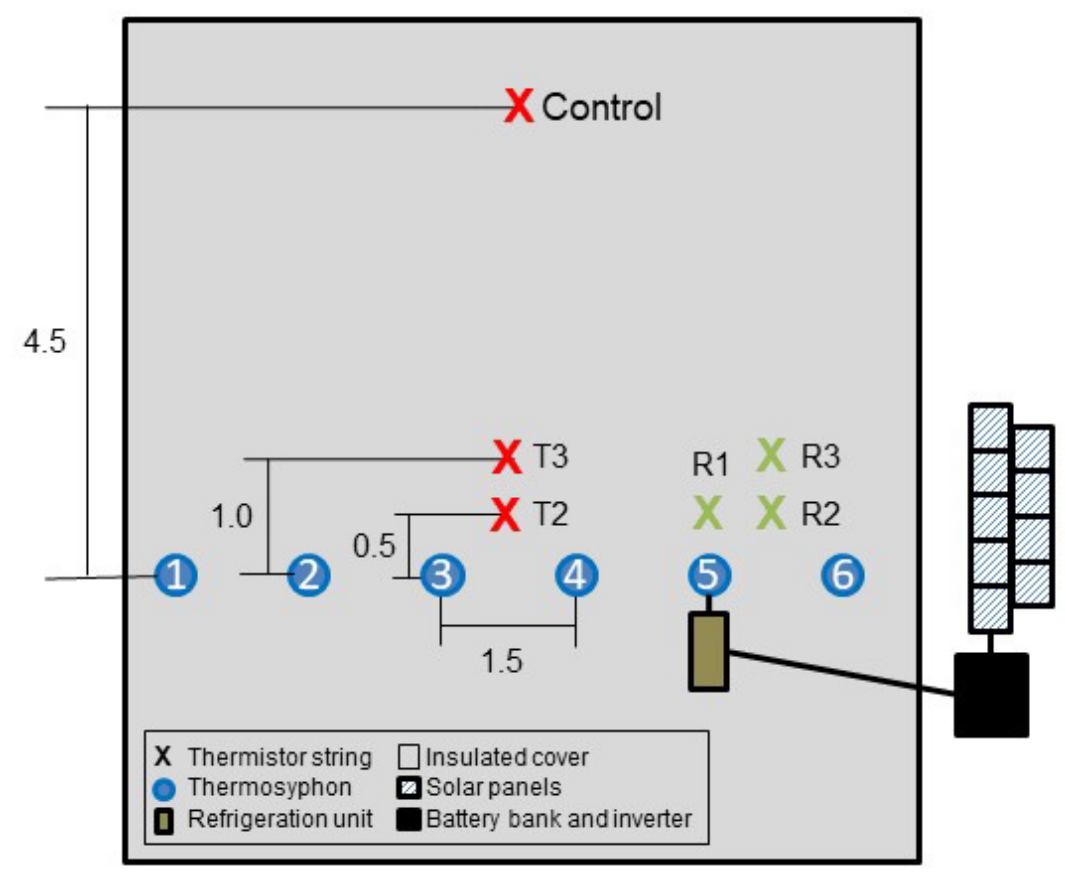


Thermosyphon \#3 (Figure 5) was nearest the ground-temperature-monitoring network from the Frozen Barrier Demonstration project, and temperature strings installed close to this thermosyphon ( $\mathrm{T}_{2}-\mathrm{T}_{3}$ and control) served as a control for the experiment. We added new ground-temperature-monitoring infrastructure (R1-R3) near thermosyphon \#5 and \#6 (Figure 5) to monitor subsurface changes and ground thermal reactions to active refrigeration. A small compressor/condenser unit was connected to thermosyphon \#5 and provided cooling as power was available (Figure 5). A solar-powered electrical system and associated power storage and distribution system provided electrical energy to the compressor/condenser unit attached to thermosyphon \#5. We observed the ground thermal regime from temperature sensors proximal to thermosyphon \#5. We compared the soil temperatures to ground thermal conditions observed close to thermosyphons \# 3 and \# 4 to determine how effective renewable-energy-based cooling was in maintaining and improving frozen ground conditions via active thermosyphon action.

\subsection{Refrigeration}

We used refrigeration pressures measured in 2011, during the active cooling of the Frozen Barrier Demonstration project, to determine the change in enthalpy between the high-pressure (liquid) line and low-pressure suction (vapor) lines. During the previous Frozen Barrier Demonstration project, a Bohn model BDTo601L6C compressor/condenser unit charged with R-404A refrigerant provided 24-hour cooling to six thermosyphons in active configuration for 62 days. Full project and ground-temperature monitoring occurred over 81 days and included the 62-day active cycle. The Bohn unit utilized a Copeland (St. Louis, Missouri, USA) brand compressor, model 3DA3F28KE-TFC-200 (Figure 4). Copeland performance characteristics indicated that this model compressor operates at a known refrigerant volume flow rate of $226 \mathrm{~kg} / \mathrm{hr}$ (Copeland 2017).

To select the refrigeration unit for this study, we estimated energy transfer rates. For this estimation, we used the change in internal energy of the refrigerant and the flow rating of the compressor during the Frozen Barrier Demonstration project. Energy transfer between all parts of the system was assumed to occur under ideal conditions. Losses were not accounted for in this estimation. Refrigerant mass flow rate and enthalpy difference were used to determine the total energy transfer of the refrigeration system for all six thermosyphons. This resultant energy value was divided by six to estimate a per thermosyphon energy transfer rate of $1109 \mathrm{~W}$. 
With this estimate, we considered three different refrigeration-condensing units based on heat removal ratings. These included (1) a $0.5 \mathrm{hp}$ Bohn BHTo05X6B hermetically sealed compressor unit (Heatcraft Refrigeration Products 2021), (2) a 0.5 hp Copeland ENAG-A05O-IAA-020 semi-hermetic condensing unit (Copeland 2017), and (3) a 0.25 hp Danfoss (Baltimore, Maryland, USA) OP-UCGCo025R hermetically sealed compressor unit (Danfoss 2020). The Danfoss unit uses refrigerant R134A, and the Bohn unit operates with a refrigerant R404A. The Copeland unit is capable of operating with R134A or R404A. The heat removal rates for each of the compressors varied (Figure 6), the highest being the Bohn unit (1660 W) at $-6.7^{\circ} \mathrm{C}$. The Copeland unit removal rate is $850 \mathrm{~W}$, and the Danfoss unit has the lowest removal rate $(570 \mathrm{~W})$. We selected the Copeland unit for this study because its heat removal rate was closest to the Frozen Barrier Demonstration project (1109 W).

Figure 6. Heat removal rates for the selected refrigeration units.

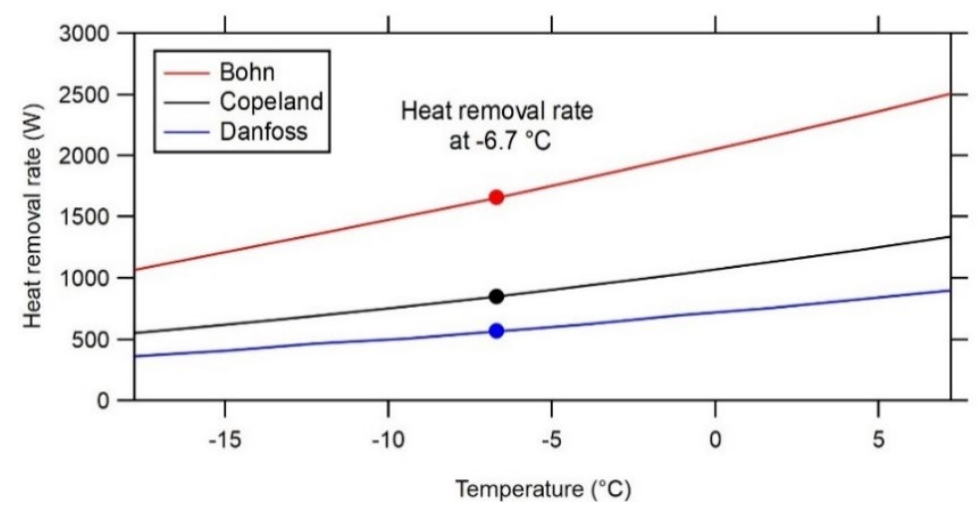

\subsection{Solar assembly}

The solar assembly system was designed around the power cost estimated for 8-hour daily operation of the compressor/condenser unit. It included a solar panel array, a load center, a charge controller, an inverter, and a battery bank (Figure 7). The solar panel array itself consisted of nine $310 \mathrm{~W}$ panels mounted on a static ground mount (Figure 8). The array fed a Conext brand (Schneider Electric, Andover, Massachusetts, USA) solar charge controller (Conext MPPT 60 150), an inverter (Conext SW $4000 \mathrm{~W}, 24 \mathrm{~V}$ ), associated AC (alternating current) and DC (direct current) breaker-panel assemblies, and a $24 \mathrm{~V}$ battery bank that consisted of eight $6 \mathrm{~V}, 224 \mathrm{Ah}$ capacity batteries (Figure 9). The inverter and charge control systems were designed to supply $120 \mathrm{~V}$ single-phase $\mathrm{AC}$ power to the compressor unit. The solar assembly controller had a low cutoff value of $50 \%$ battery capacity and a cut-in value of $80 \%$ capacity. If battery-bank charge capacity fell 
below 50\%, the compressor shut off and remained off until battery bank charge capacity was $80 \%$ or better. An auxiliary circuit powering three fans was added to the load center to help circulate air over the thermosyphon heat exchanger and improve passive-mode efficiency. Results from the fan operation are not a part of this report.

Solar assembly performance measurements were logged using a Conext ComBox communication and data monitoring system (Figure 9). It operated on a 10-minute interval and stored measurements to a compact flash card, to be downloaded manually.

Figure 7. Solar assembly diagram.

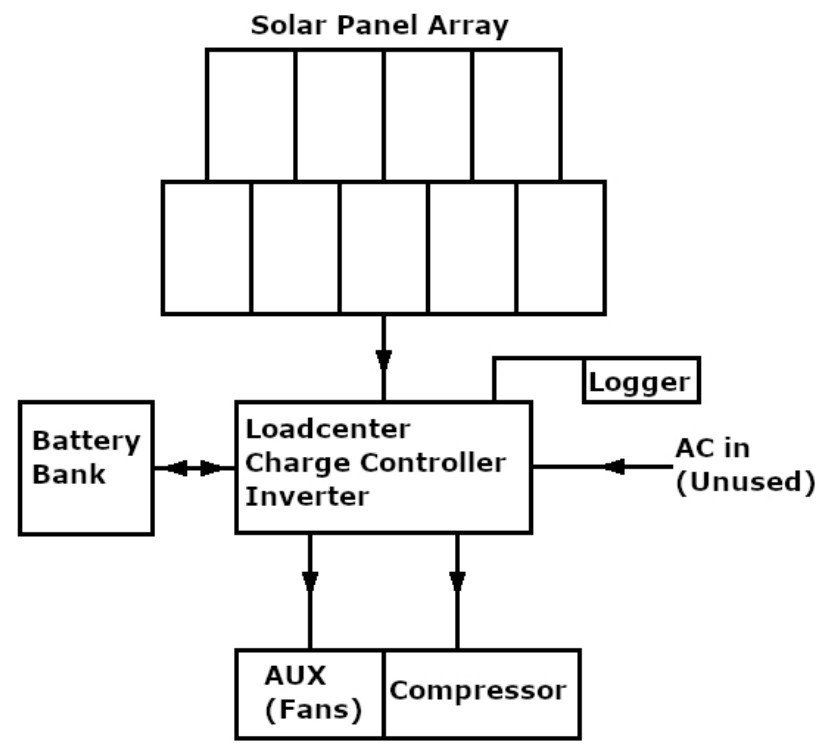

Figure 8. Solar panel array.

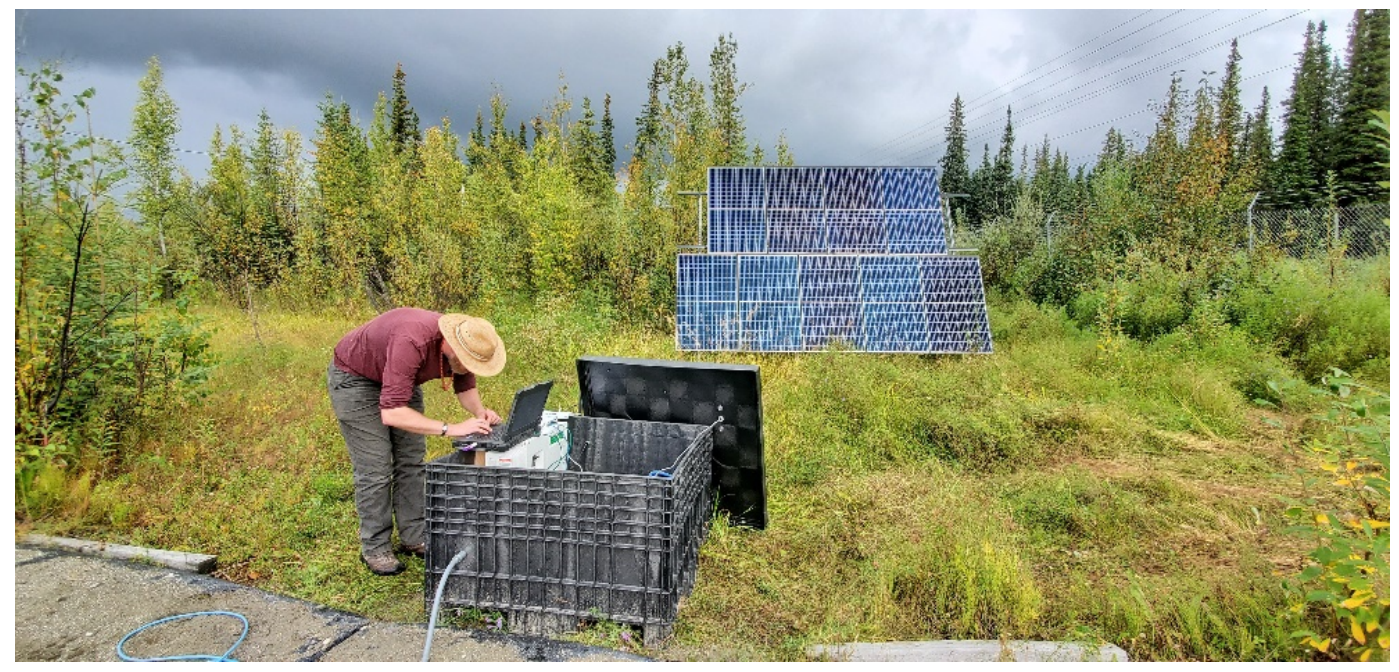


Figure 9. Conext ComBox communication and data monitoring system and the battery bank.

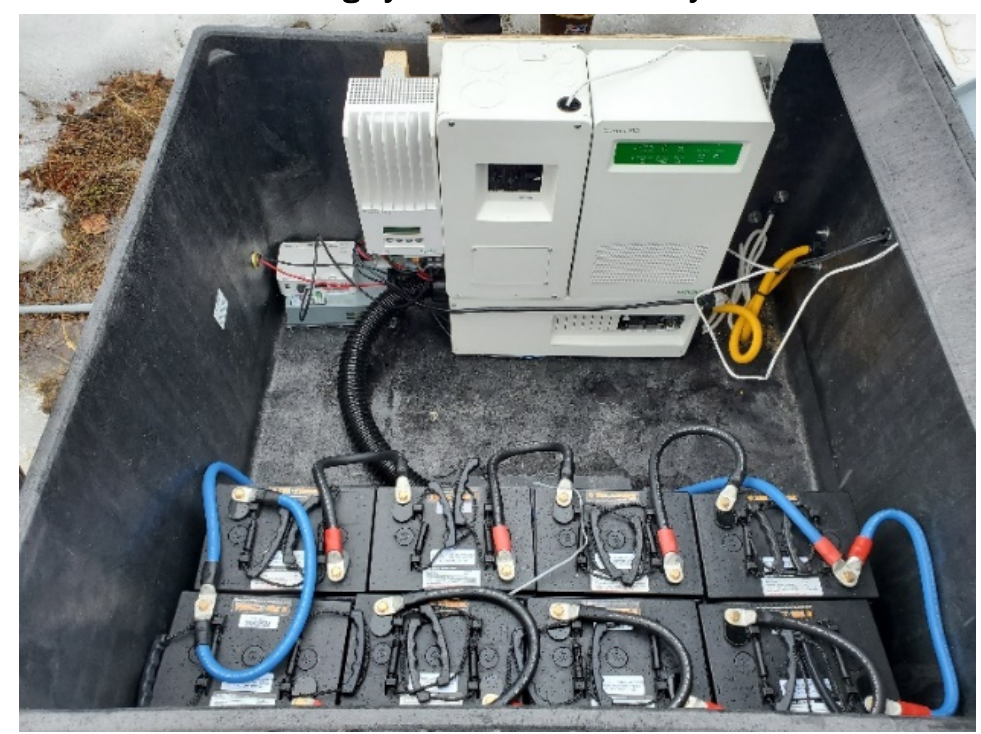

\subsection{Temperature monitoring}

Portions of the ground-temperature-monitoring system installed during the original Frozen Barrier Demonstration project were still operational. The locations of the operational temperature strings provided background data for this project and are marked in Figure 5 (T2, T3, and control). In fall 2019, we installed three additional ground-temperature-monitoring strings (R1-R3) with a Geoprobe (Salina, Kansas, USA) 7822 track-mounted direct push drill rig (Figure 10). We installed temperature strings in proximity to thermosyphon \# 5 ( $\mathrm{R}$ temperature strings in Figure 5 ). These were operated by the refrigeration unit and were in a similar array and in similar locations as the T temperature strings. Figure 11 illustrates the thermistor placement depth, and Figure 12 shows the sensor placements.

The T series temperature strings included three BeadedStream (Anchorage, Alaska, USA) digital temperature strings, logged hourly with a BeadedStream data logger. The R series temperature strings consisted of an Onset HOBO (Bourne, Massachusetts, USA) U30, which logged fifteen STMB type 12-bit smart temperature sensors. The U30 data logger had been in operation since fall 2019 and recorded temperatures at 10-minute intervals. We added four additional temperature sensors (TMC-HD type) to the $\mathrm{R}$ series temperature strings (R1-R3) on 8 September 2020 and were connected to a U12 data logger, also manufactured by Onset. 
Figure 10. Installation of thermistor string casings (R1-R3) with a Geoprobe 7822.
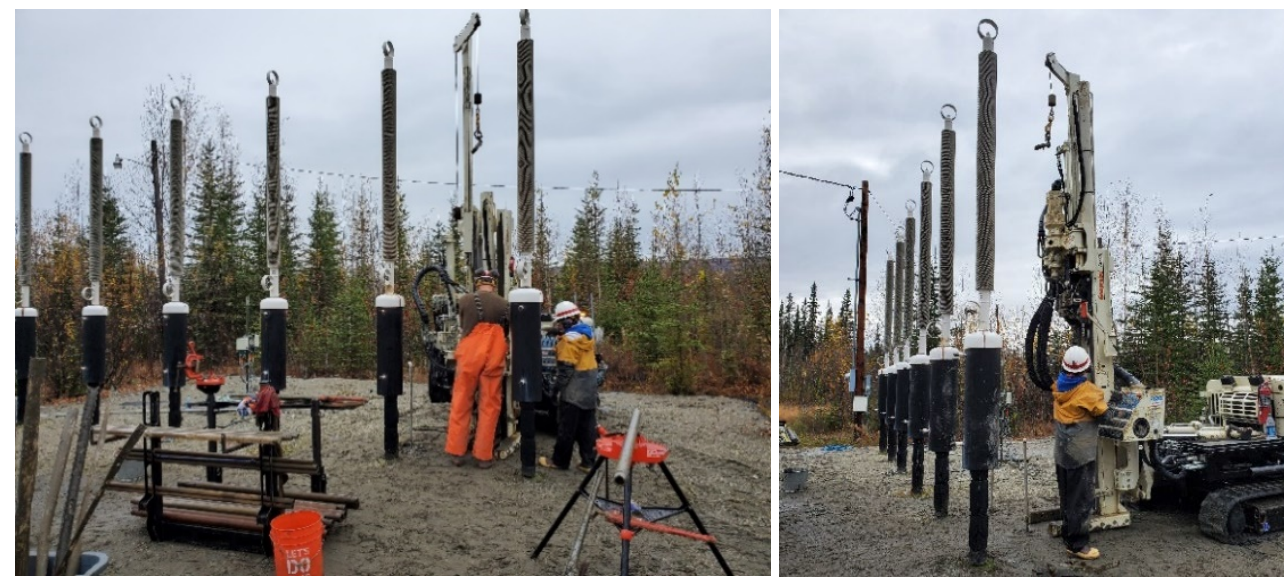

Figure 11. Ground-temperature-monitoring layout. Old and new infrastructure as compared to thermosyphon infrastructure at the test site. At the time of initial installation, the depth to permafrost was $7 \mathrm{~m}$ (see Fig. 12).

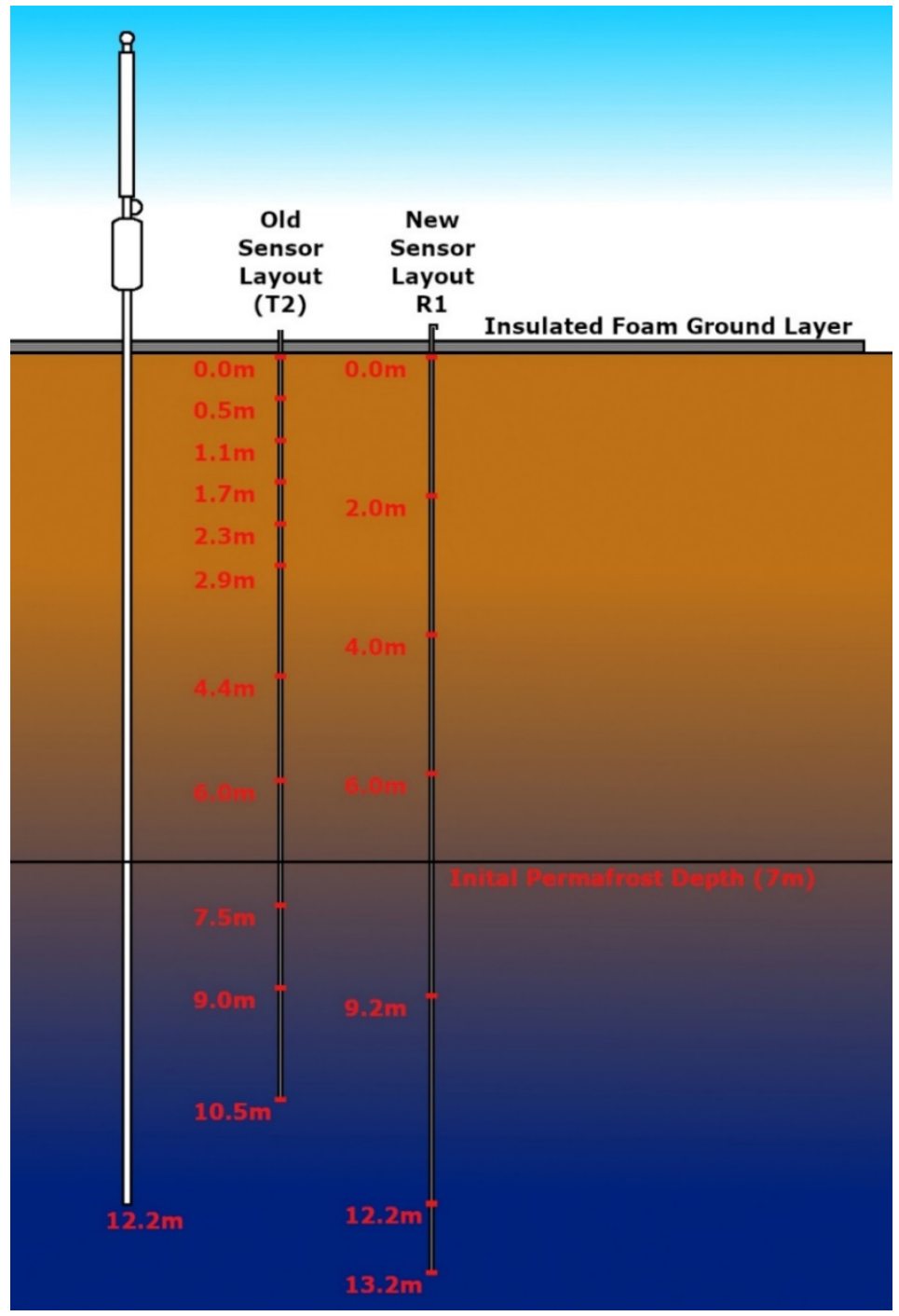


Figure 12. Temperature-sensor depths. Temperaturemonitoring-string numbers and associated sensor depths.

The dashed line indicates depth to frozen ground as measured with temperature strings in 2011 (prior to artificial freezing of the site).

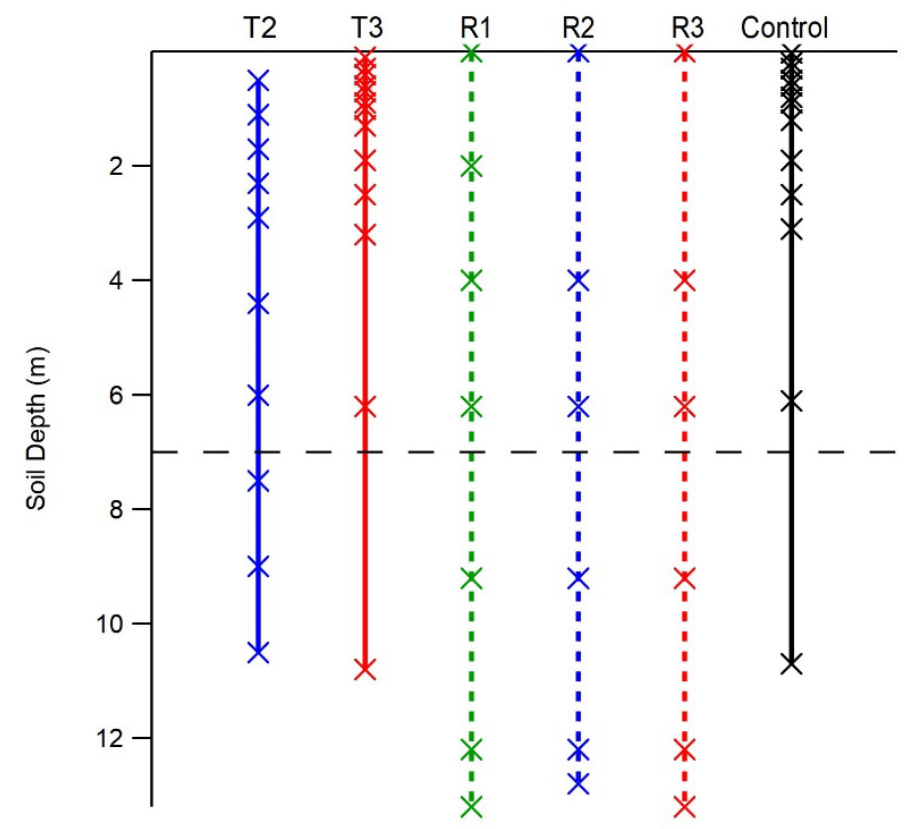




\section{Results and Discussion}

\subsection{Refrigeration unit selection}

The refrigeration system was sized assuming that heat transfer between the refrigeration unit and the condenser section of the thermosyphon was without heat loss. Additionally, energy transfer in the evaporator section was assumed to represent the entirety of energy absorbed in the thermosyphon. Most heat transfer occurs in the bottom regions of the thermosyphon where the liquid refrigerant is collected (Yarmak and Zottola 2017).

During the Frozen Barrier Demonstration project, the vertical temperature profile near thermosyphons \# 3 and \#4 indicated that certain sections of the thermosyphon were reacting (i.e., cooling) more quickly than other sections. Soil-temperature monitoring showed a faster cooling at a soil depth between about $7 \mathrm{~m}$ and $11 \mathrm{~m}$ belowground than at shallower depth sensors (Figure 13). This colder region ( $7 \mathrm{~m}$ to $11 \mathrm{~m}$ ) indicated that it was in or near the liquid-bath section of the thermosyphon evaporator and therefore in the zone most responsible for heat exchange over the height of the thermosyphon.

Figure 13. Soil temperatures during active and passive phases for a control temperature string (top) and a midpoint temperature string between the \#3 and \#4 thermosyphons (bottom) (revised from Wagner 2013). Silt soils are encountered down to depths of at least $10 \mathrm{~m}$. The white field in the lower panel corresponds to missing data due to battery malfunction.

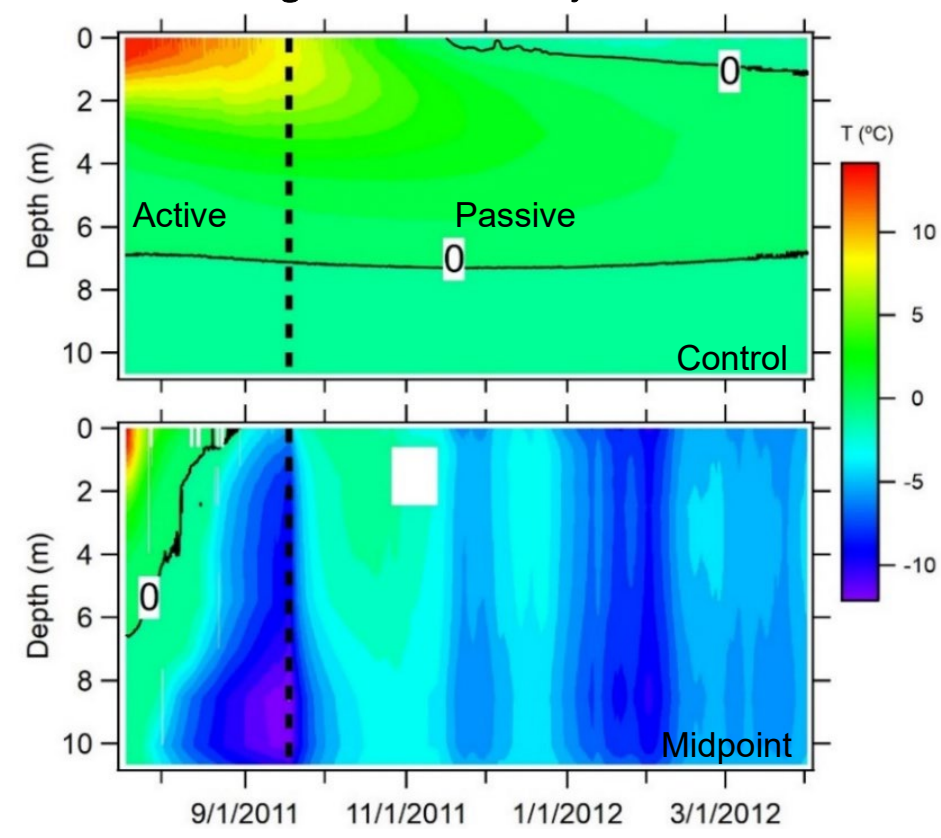


For a best estimate of the soil degree change per watt extracted, we combined heat removal rates and ground temperature trends in the zone most responsible for ground heat extraction. Manufacturer performance data for all three refrigeration units was used to interpolate heat extraction rates between a $-6^{\circ} \mathrm{C}$ cold sink (thermosyphon condenser) and $24^{\circ} \mathrm{C}$ ambient atmospheric conditions. With this, we estimated resultant ground temperatures likely to be seen near the liquid-bath section of the thermosyphon evaporator at heat extraction rates of 290, 580, 870, and $1160 \mathrm{~W}$ (Figure 14).

Figure 14. Estimated ground cooling for different heat removal rates of (a) $290 \mathrm{~W},(b) 580 \mathrm{~W}$, (c) $870 \mathrm{~W}$, and (d) $1160 \mathrm{~W}$ at the Frozen Barrier Demonstration site.
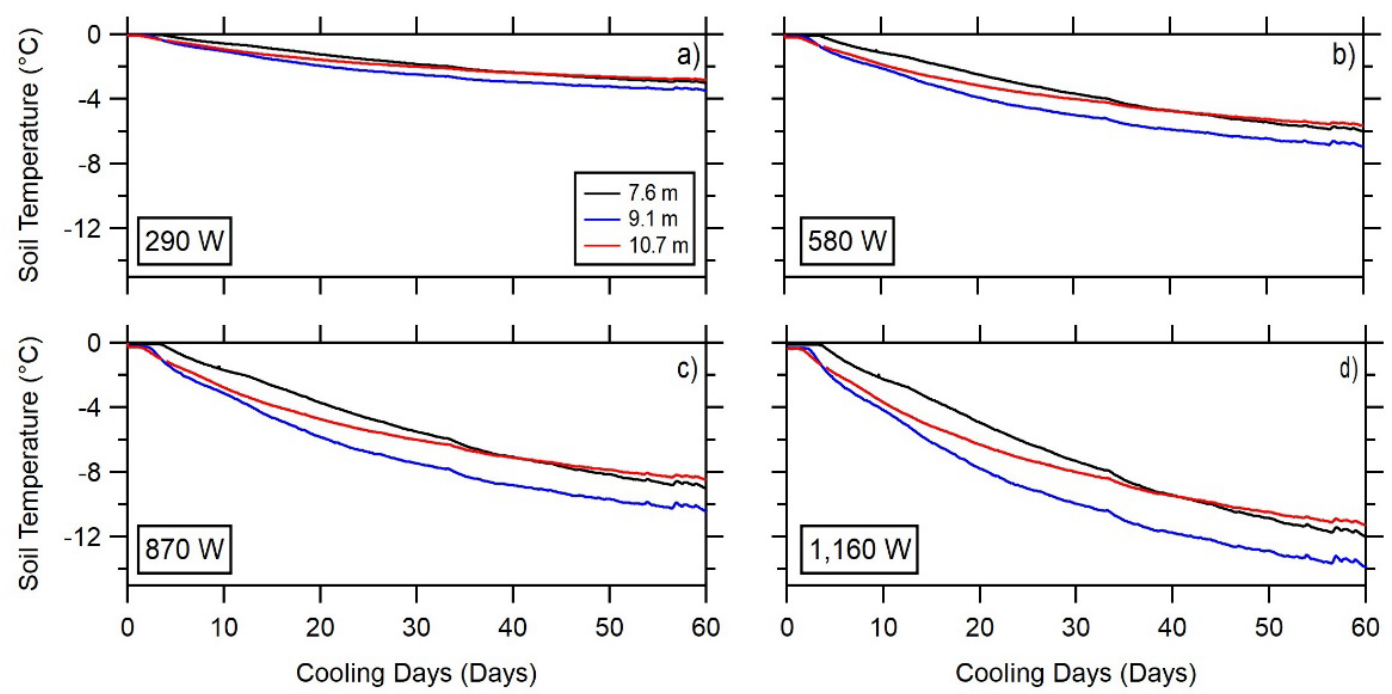

We chose an extraction rate of $870 \mathrm{~W}$ for our selection criterion because it fit the targeted heat removal rate. As per this interpolation, the Copeland unit (Figure 15) fell closest to selected heat extraction rates. We selected the Copeland unit, therefore, over two other condensing units (Danfoss and Bohn) that we had identified as potential units for this test. In addition to the heat removal rates closest to the criteria for this case study, the Copeland unit operates on single-phase power versus three-phase power required for the Bohn unit. Single-phase power requires less power infrastructure and, by extension, is a simpler solar installation. The Copeland unit was also a fairly economically priced unit. Finally, the Copeland unit demonstrated a greater flexibility in refrigerant type, capable of operating with R134A, R404A, or R22. Figure 16 shows the Copeland unit and solar panel array field installation. 
Figure 15. Refrigeration unit, a Copeland ENAG-A050-IAA-020.

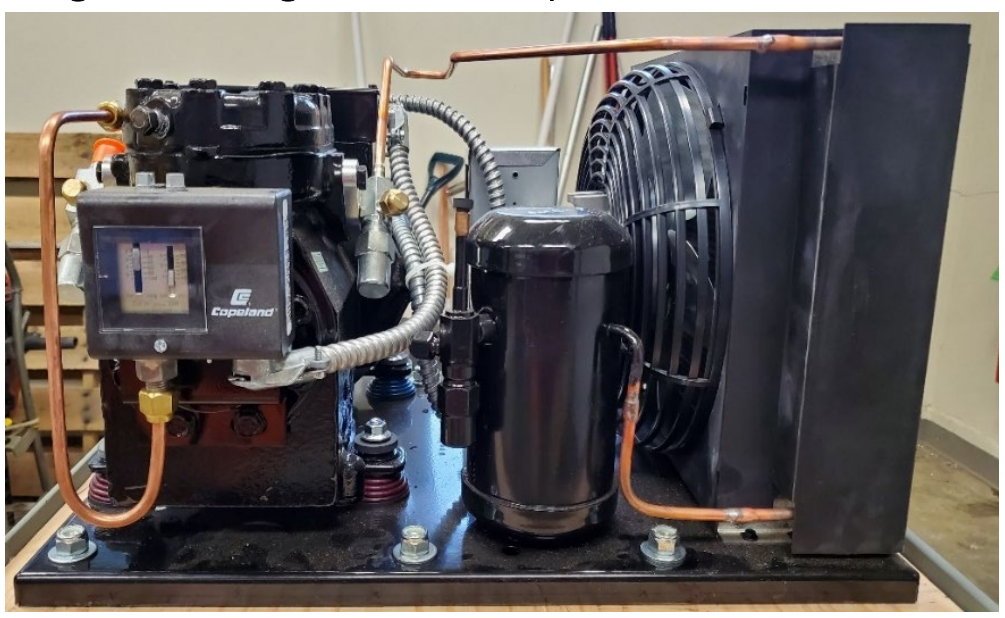

Figure 16. Refrigeration and solar panel installed at the frozen barrier field site.

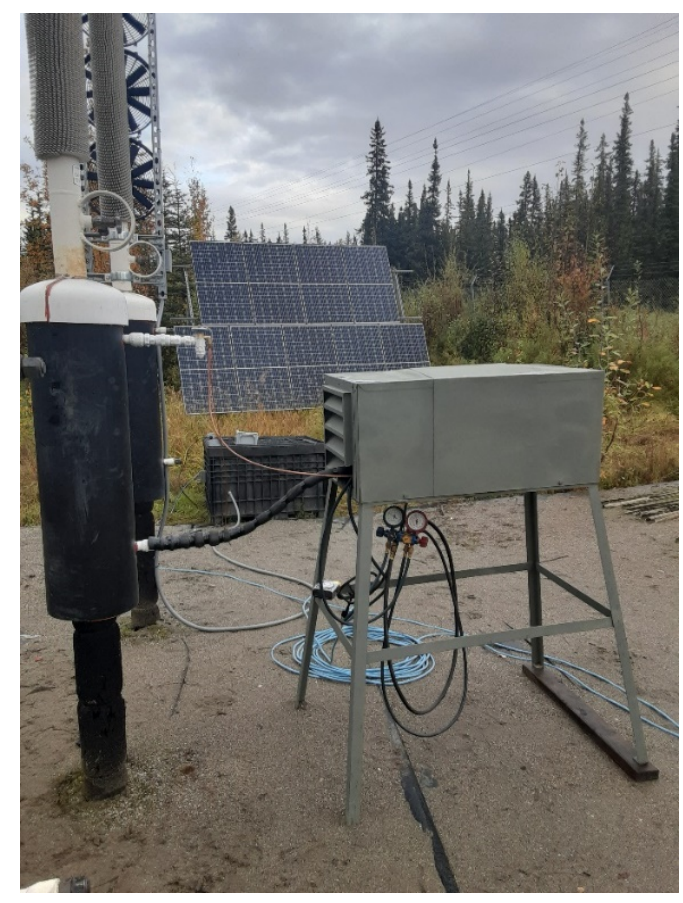

\subsection{Soil temperatures prior to active cooling}

Prior to the installation of the new refrigeration unit and solar array, soil temperatures at the frozen barrier were monitored using previously installed temperature strings, with data since fall 2018. The existing temperature strings were in the proximity of thermosyphons \# 3 and \#4 at a distance of $0.5 \mathrm{~m}$ and $1.0 \mathrm{~m}$ off center from the row of thermosyphons (see T2 
and $\mathrm{T}_{3}$ in Figure 5). The previously installed temperature strings also included a control temperature string at a distance of $4.5 \mathrm{~m}$ from the center of the row of thermosyphons.

Figure 17 shows the air temperature, precipitation, and solar radiation at the Fairbanks International Airport for 2018-2020. The average air temperature for 2020 was about $3^{\circ} \mathrm{C}$ colder than for 2019. In fact, 2019 was the warmest recorded $\left(0.4^{\circ} \mathrm{C}\right)$ in the last 90 years (see Figure 2). Only in one other year (1981) has the mean annual air temperature been above freezing.

Figure 17. Air temperature ( 5 min averages, black line), solar radiation ( 5 min averages, blue line), and precipitation (daily, red bars) at the Fairbanks International Airport, Alaska.
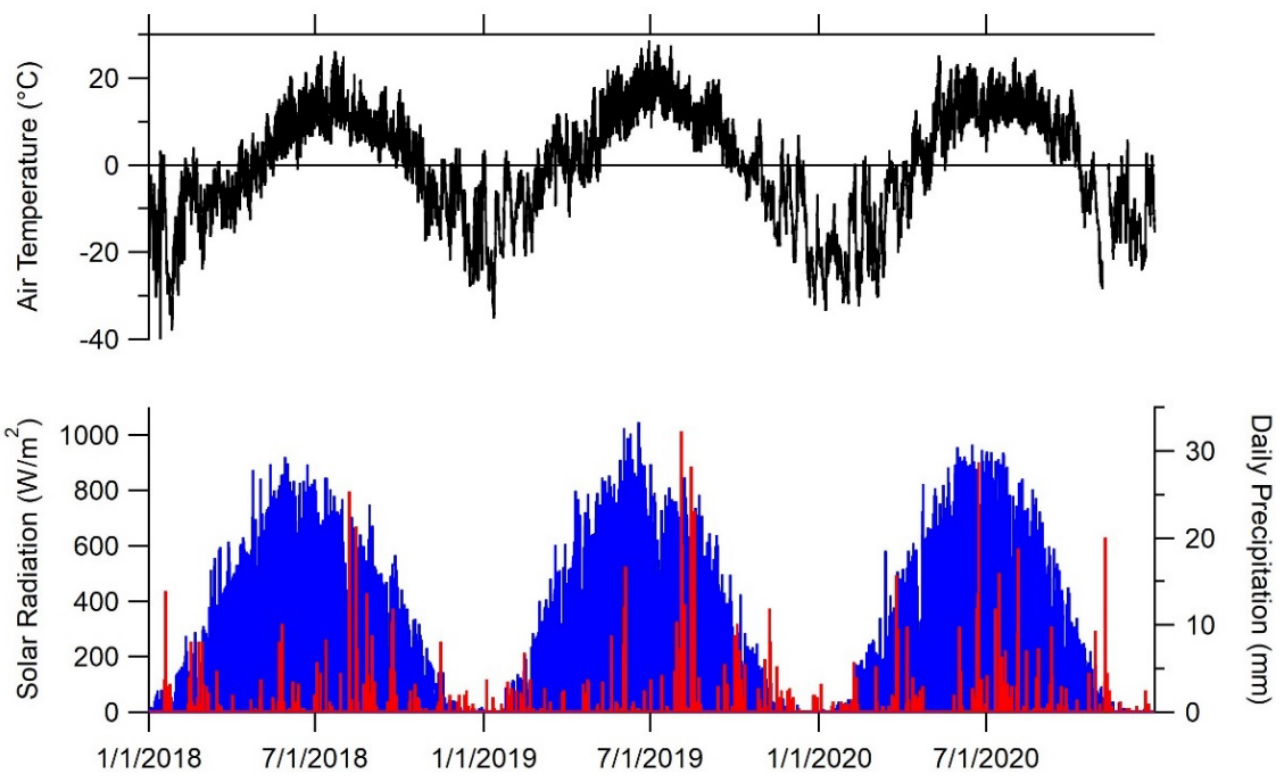

Similar to what was seen in 2012 (Wagner and Yarmak 2017), soil temperatures at up to $1.0 \mathrm{~m}$ horizontal distance away from the frozen barrier (T2 and $\mathrm{T}_{3}$ ) remained frozen throughout the year (Figure 18). At a depth of $0.5 \mathrm{~m}$, the temperature at the control was slightly below freezing in the winter and above freezing during the summer months (a maximum of $7.2^{\circ} \mathrm{C}$ ). Soil temperatures in summer 2019 at this depth were up to $7 \cdot 3^{\circ} \mathrm{C}$ higher at the control compared to temperatures observed proximal to the frozen barrier. At a depth of $10.0 \mathrm{~m}$, the soil was frozen throughout the year, both in proximity to the frozen barrier and at the control site. The soil temperatures at $\mathrm{T} 2$ and $\mathrm{T} 33$ were about $0.5^{\circ} \mathrm{C}$ colder than at the control. During the low air temperatures in January 2019, the soil temperatures at $\mathrm{T} 2$ were $4.5^{\circ} \mathrm{C}$ and $6.0^{\circ} \mathrm{C}$ lower than at the control site at a depth 
of $10.0 \mathrm{~m}$ and $0.5 \mathrm{~m}$, respectively. At a depth of $10.0 \mathrm{~m}$, the soil temperatures at $\mathrm{T} 3$ were about $1.0^{\circ} \mathrm{C}$ higher than at $\mathrm{T} 2$. This difference was slightly more $\left(1.5^{\circ} \mathrm{C}\right.$ higher $)$ at a depth of $0.5 \mathrm{~m}$.

Figure 18. Soil temperatures between thermosyphon \#3 and \#4 at $0.5 \mathrm{~m}$ (top) and $10.0 \mathrm{~m}$ (bottom). Some loss of data occurred due to logger battery failure in winter 2020.

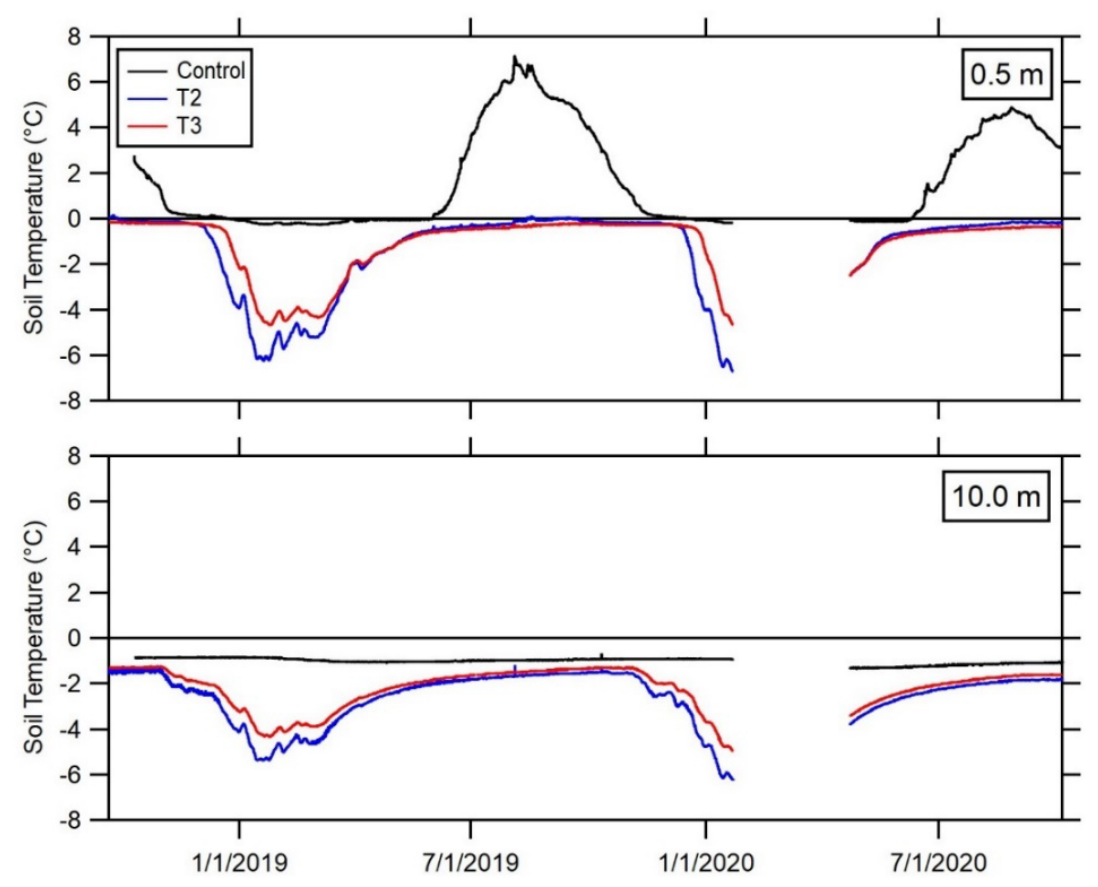

Soil-temperature curves for the $\mathrm{T}$ strings at different times of the year (13 January, 1 May, and 1 September 2019) reinforce that the temperatures were lower than the control at all $\mathrm{T}$ locations (Figure 19). At the control site, soil temperatures were above freezing down to a depth of about $5 \mathrm{~m}$. At the frozen barrier, thawing was down to a depth of only about 0.5 $\mathrm{m}$, which was similar to results reported by (Wagner and Yarmak 2017).

We compared the soil temperatures near the refrigeration unit ( $\mathrm{R}$ strings) and control (T strings) on 1 January 2020 prior to starting the refrigeration unit (Figure 20). The soil temperatures were slightly lower near thermosyphons \# 3 and \#4 when compared to thermosyphons \# 5 and \#6. The soil-temperature difference was about $1.5^{\circ} \mathrm{C}$ between the soil depths at $0.5 \mathrm{~m}$ and $1.0 \mathrm{~m}$ from the center line of the thermosyphons (see temperatures from strings $\mathrm{T}_{2}$ and R2, and $\mathrm{T}_{3}$ and $\mathrm{R}_{3}$ in Figure 20). 
Figure 19. Soil-temperature curves for the T strings (T2, T3, and control) on 13 January (left), 1 May (middle), and 1 September (right) 2019. See temperature-string placement in Fig. 5.
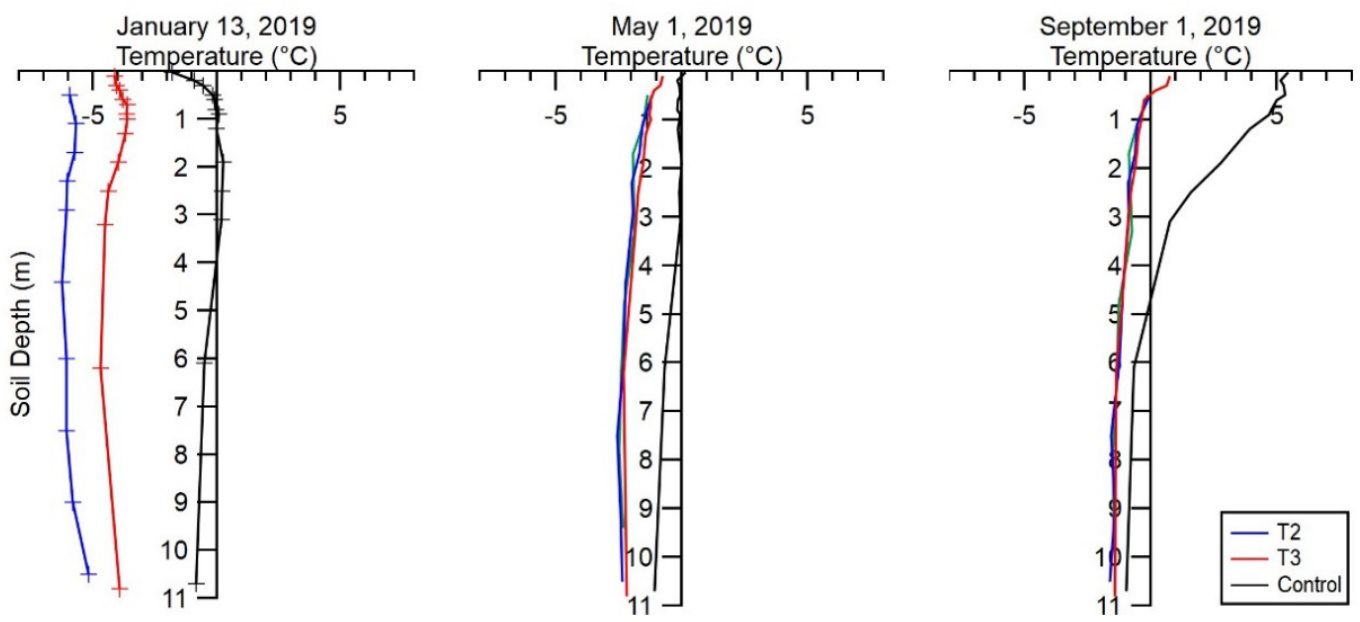

Figure 20. Soil-temperature curves $(6.0$ to $11.0 \mathrm{~m})$ on 1 January 2020 (before active refrigeration) at control (black line), between thermosyphons \#3 and \#4 (T2 and T3, solid red and blue lines), and between thermosyphons \#5 and \#6 (R2 and R3, dashed red and blue lines).

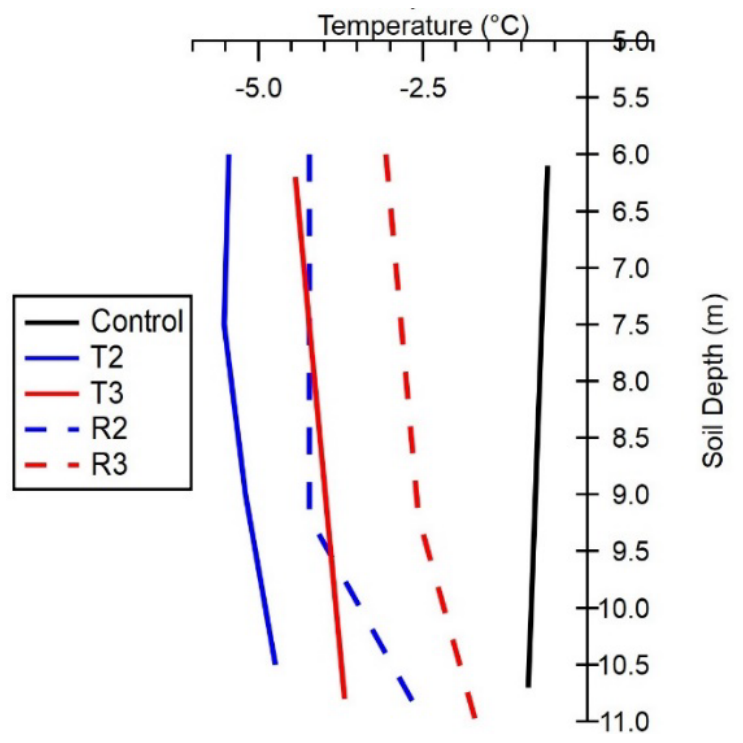

\subsection{Artificial cooling in the active phase}

Artificial cooling using the refrigeration unit started on 26 August 2020. To ensure a recharge of the solar battery bank, the refrigeration unit was cycled on and off throughout testing except at the initial start-up, which included a constant run time of 11 hours. The unit cycled on and off in 2-hour increments when solar power was available, and it automatically shut down when the battery bank dropped below the cutoff value of $50 \%$ total battery capacity. 
As expected, there was a direct response in cooling of the soil temperature when refrigeration was active and warming of the soil when the refrigeration system was dormant (Figure 21). The soil-temperature monitoring shows that heat removal and cooling of the soil occurred along the entire underground section of the thermosyphon while the greatest degree of cooling was observed at the bottom of the thermosyphon in the liquid-bath section. The control strings ( $\mathrm{T}$ strings) stopped logging on 5 October 2020 because of a battery malfunction. No cooling in proximity to thermosyphons \# 3 and \#4 (T strings) occurred up to that date (see T string in Figure 21). Mean daily air temperatures below freezing occurred on 12 October 2020.

Figure 21. Soil temperatures between thermosyphon \#5 and \#6 at a depth of (a) $2.0 \mathrm{~m}$, (b) $4.0 \mathrm{~m},(c) 6.0 \mathrm{~m}$, and (d) $9.2 \mathrm{~m}$ from 15 August to 31 October 2020 and $(e)$ Daily air temperature at the Fairbanks International Airport, Alaska.
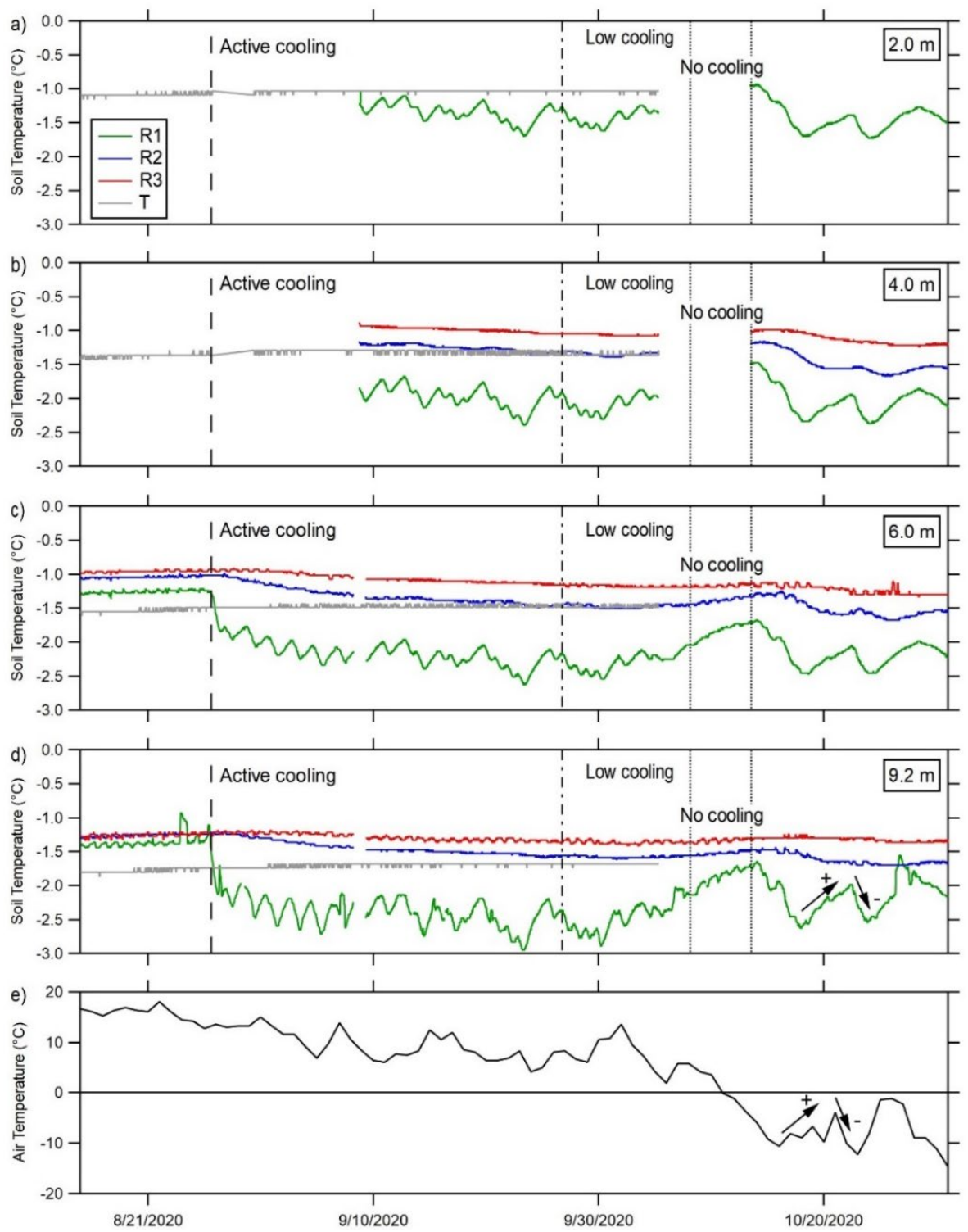
The active system was shut off on 23 October 2020 when air temperatures were favorable and cold enough for the passive system to operate without power. A decline in soil temperature was evident even though the active system was dormant. This was demonstrated by the direct response of a decrease/increase in soil temperature when there was a decrease/increase in air temperature (see Figure 21). At the onset of cooling air temperatures, there was a delay of about 36 hours until a decrease in soil temperature at a depth of $9.2 \mathrm{~m}$.

Figure 22 shows soil temperatures at a depth of $9.2 \mathrm{~m}$ (at R1), battery voltage, photovoltaic (PV) total power, and load power. There is a decline in load power caused by a leaking valve of the refrigeration hookup, which occurred from the end of September through 7 October 2020 (see "Low cooling" in Figure 22). This decline resulted in increasing soil temperatures during this time. No refrigeration cooling occurred until repairs could happen; the system was fully operational again on 13 October 2020 ("No cooling" in Figure 22). During this period (6 days), which simulated a system shut off, the soil temperatures at a depth of $9.2 \mathrm{~m}$ experienced only a limited temperature increase of $0.4^{\circ} \mathrm{C}$. The temperature increase at a depth of $6 \mathrm{~m}$ was even less $\left(0.3^{\circ} \mathrm{C}\right)$. Snow falling on 19 October 2020 covered the solar panels for a few days and resulted in no power generation and limited the battery-bank recharge during that time (see no generated power in "PV Total P" Figure 22).

An increase in PV power was in direct response to the available sunlight, which was affected by sunrise and sunset, cloud cover, and precipitation events. This was reflected in the collected data where, in between sunrise and sunset as illustrated in the light gray field in Figure 22, the PV power increased during available solar radiation (see orange line in Figure 22). Precipitation events and cloud cover caused a decline in PV power. Daily maximum solar radiation during the testing period was about $800 \mathrm{~W} / \mathrm{m}^{2}$ (end of August) and decreases to about $50 \mathrm{~W} / \mathrm{m}^{2}$ at the end of October (see Figure 17 and orange line in Figure 22). A maximum PV power of about $1700 \mathrm{~W}$ was recorded throughout the period of testing. The peak occurred in the afternoon from about 1500 to 1600 hours. Lower daily PV power peaks (about $400 \mathrm{~W}$ ) were recorded throughout the testing period during either rain events or cloudy days. Low PV values were also recorded when the battery bank was fully charged and no load was applied to the system (starting about 9 October 2020). 
During available sunlight and solar radiation (see light gray field and orange lines in Figure 22), the direct response in the increase of voltage of the battery bank is clearly evident. When the refrigeration system was operating, there was a direct decrease in battery power. If enough battery voltage was available, the refrigeration system was still operational even if the PV power was not charging the battery bank.

On average, the maximum load of the refrigeration unit was about $840 \mathrm{~W}$, which was close to the maximum load rated for the Copeland unit (850 W). A slight decrease in load (about $150 \mathrm{~W}$ ) to about $700 \mathrm{~W}$ while the refrigeration unit was operating was also evident at the end of most 2-hour cycles.

Figure 22. Soil temperature at $9.2 \mathrm{~m}$ (R1 temperature string), battery voltage (blue line), PV total power (black line), and load power (red line) for 26 August to 31 October 2020 (top) and 26 August to 4 September 2020 (bottom). Dark gray bars show precipitation (P.), and solar radiation at the Fairbanks International Airport is shown in orange. Light gray fields (bottom) indicate sunrise to sunset.
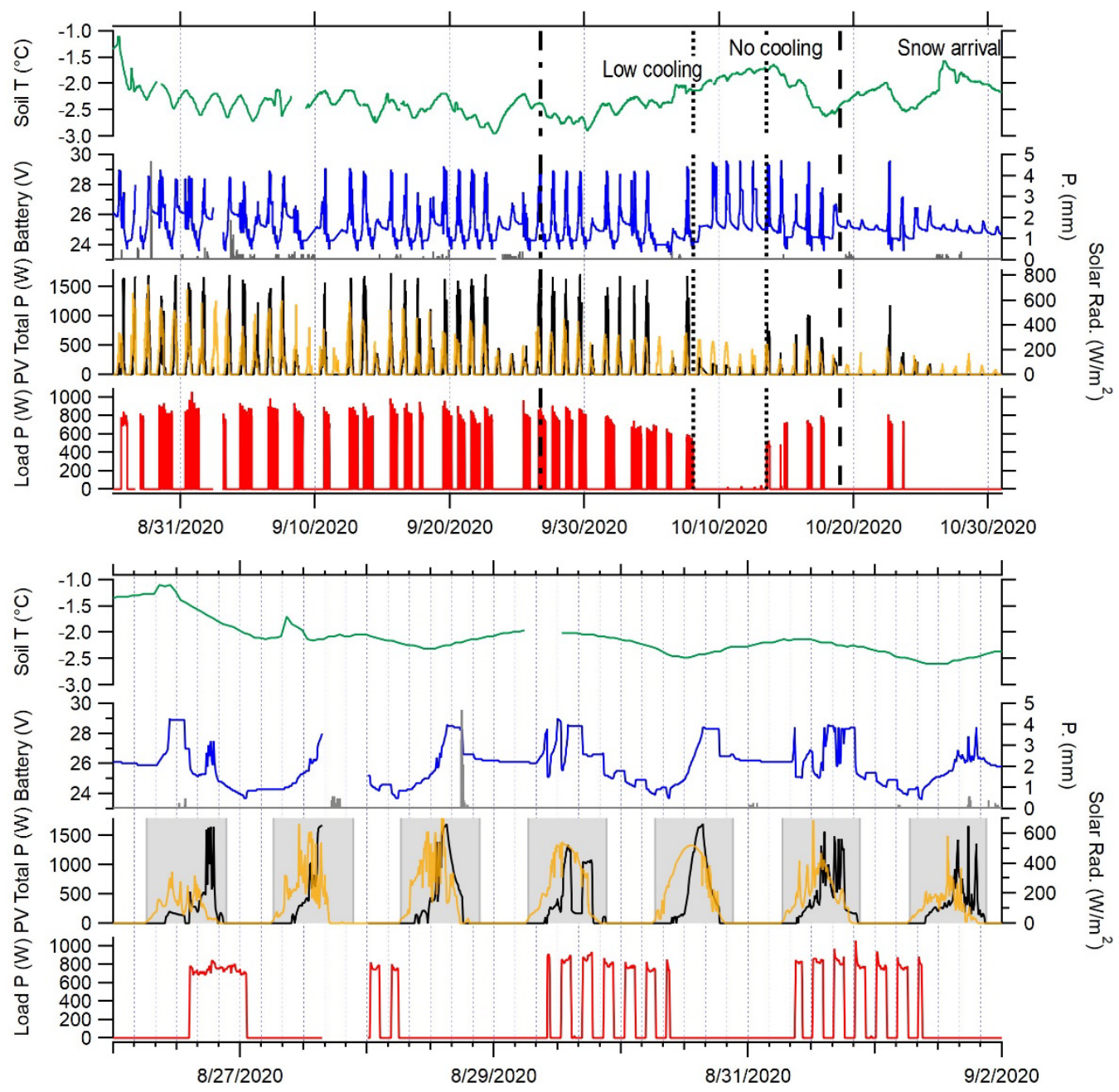


\section{Conclusions and Recommendations}

The goal of this project was to test if a solar array could power a refrigeration unit to support the application of hybrid thermosyphons. We chose a 0.5 HP Copeland ENAG-A050-IAA-020 semi-hermetic condensing unit for this study because it fit the energy-removal criteria for our test site. The maximum load for this Copeland unit was $850 \mathrm{~W}$. The solar array total wattage was $2790 \mathrm{~W}$, and the peak total power generated during the testing was $1700 \mathrm{~W}$. The Copeland compressor unit successfully cooled the soil by using a solar power energy source. This system could extend the time each year that thermosyphons can actively freeze or cool subsurface soils.

Using a solar array as large as we used in this project to operate one thermosyphon is not economically feasible, and therefore future research should explore other low-powered refrigeration units. For the system tested in this study, it would also be important to consider whether the selected refrigeration unit could operate multiple thermosyphons as that would make this system more economically justifiable. Future investigations need to include refining and defining the limits of different refrigeration units and solar panel arrays and how to extrapolate for other configurations. For example, for our tested system, except for the initial startup of the system, we did not determine if this unit could operate for a longer duration than 2-hour intervals. Could the unit operate for a longer period during daylight hours when there is available sunlight and when the battery bank can recharge in tandem with operating the refrigeration unit? Are there other low-powered refrigeration units or similar systems that can be tested for this?

Overall, our study shows that active thermosyphons operated by a solar array system can be used to artificially freeze or maintain frozen ground in locations where line power is limited or unavailable. Additionally, our results illustrate that this system can be used as a part of a retrofit system for current thermosyphon infrastructure that depends on the maintenance of frozen ground during a warming climate. 


\section{References}

Copeland. 2017. Copeland E-Line: Copelametic Air-Cooled and Water Cooled Condensing Units. St. Louis, MO: Emerson. https://climate.emerson.com/documents L03-2011ds-4-e-line-r1-en-3948226.pdf.

Daggett, A. P., J. D. Thornley, E. Yarmak, J. Zarling, and S. Mehta. 2019. “Construction Ground Freezing-A Look at Modeled versus Measured Performance.” In Cold Regions Engineering 2019. Reston, VA: American Society of Civil Engineers. https://doi.org/10.1061/9780784482599.044.

Danfoss. 2020. Optyma Condensing Units. AF230886440512en-001101. Baltimore, MD: Danfoss. https://assets.danfoss.com/documents/150973/AF230886440512en-001101.pdf.

DenHartog, S. L. 1988. "A Thermosyphon for Horizontal Applications.” Cold Regions Science and Technology 15 (3): 319-321. https://doi.org/10.1016/0165 -232X(88)90078-X.

Douglas, Thomas A., M. Torre Jorgenson, Mikhail Z. Kanevskiy, Vladimir E. Romanovsky, Yuri Shur, and Kenji Yoshikawa. 2008. "Permafrost Dynamics at the Fairbanks Permafrost Experimental Station near Fairbanks, Alaska.” In Proceedings of the Ninth International Conference on Permafrost, edited by Douglas L. Kane and Kenneth M. Hinkel, 373-378.

Esch, David C. 1996. "Roads and Airfield Design for Permafrost Conditions." In Roads and Airfields in Cold Regions: A State of Practice Report, edited by Ted S. Vinson, James W. Rooney, and Wilbur H. Haas, 121-149. New York: ASCE Publications.

French, Hugh M. 2007. The Periglacial Environment. Chichester, UK: John Wiley \& Sons.

Haynes, F. D., and J. P. Zarling. 1988. "Thermosyphons and Foundation Design in Cold Regions." Cold Regions Science and Technology 15 (3): 251-259. https://doi.org/10.1016/0165-232X(88)90072-9.

Heatcraft Refrigeration Products. 2021. Installation and Operations Manual: H-IM-CU, Part No. 25008101, Condensing Units. H-IM-CU-0221, Version 004. Stone Mountain, GA: Heatcraft Refrigeration Products. https://www.heatcraftrpd.com/PDF/I\&O/H-IM-CU.pdf.

Jamieson, Heather E. 2014. "The Legacy of Arsenic Contamination from Mining and Processing Refractory Gold Ore at Giant Mine, Yellowknife, Northwest Territories, Canada." Reviews in Mineralogy and Geochemistry 79 (1): 533-551. https://doi.org/10.2138/rmg.2014.79.12.

Lader, Rick, John E. Walsh, Uma S. Bhatt, and Peter A. Bieniek. 2020. “Anticipated Changes to the Snow Season in Alaska: Elevation Dependency, Timing and Extremes." International Journal of Climatology 40 (1): 169-187. https://doi.org/10.1002/joc.6201. 
Long, E. L. 1966. “The Long Thermopile.” In Proceedings, Permafrost International Conference, 11-15 November 1963, Lafayette, IN, 487-491. Publication No. 1287. Washington, DC: National Academy of Sciences. https://www.uspermafrost.org/assets/docs/Publications/Proceedings/01st\%20International\% 20Conference\%20on\%20Permafrost $\% 20-\% 20$ Proceedings $\% 20$ \%20Lafayette\%20Indianna\%201966.pdf.

National Weather Service. 2017. Fairbanks Area Frost and Growing Season Information. Silver Spring, MD: National Weather Service. https://www.weather.gov/media/afg/climate/Fairbanks_growing_season.pdf.

Wagner, A. M. 2013. "Creation of an Artificial Frozen Barrier Using Hybrid Thermosyphons.” Cold Regions Science and Technology 96 (December): 108116. https://doi.org/10.1016/i.coldregions.2013.08.008.

Wagner, Anna M. 2014. Review of Thermosyphon Applications. ERDC/CRREL TR-14-1. Hanover, NH: U.S. Army Engineer Research and Development Center, Cold Regions Research and Engineering Laboratory. http://hdl.handle.net/11681/5564.

Wagner, Anna M., and Edward Yarmak Jr. 2012. Demonstration of an Artificial Frozen Barrier. ERDC/CRREL TR-12-12. Hanover, NH: U.S. Army Engineer Research and Development Center, Cold Regions Research and Engineering Laboratory. http://hdl.handle.net/11681/5461.

—. 2017. Using Frozen Barriers for Containment of Contaminants. ERDC/CRREL TR17-14. Hanover, NH: U.S. Army Engineer Research and Development Center, Cold Regions Research and Engineering Laboratory.

http://dx.doi.org/10.21079/11681/23958.

Wagner, Anna M., John P. Zarling, E. Yarmak, and Erwin L. Long. 2010. “Unique Thermosyphon Roadway Test Site Spanning 11 Years." In Proceedings of GeoCalgary 2010: the 63rd Canadian Geotechnical Conference and 6th Canadian Conference on Permafrost, 12-15 September, Calgary, Alberta, Canada. http://pubs.aina.ucalgary.ca/cpc/CPC6-1770.pdf.

Yarmak, E., and E. Long. 2012. "The Performance of a Flat-Loop Evaporator Thermosyphon at Deadhorse, Alaska." In Proceedings, Cold Regions Engineering 2012, 19-22 August, Quebec City, Canada. https://doi.org/10.1061/9780784412473.035.

Yarmak, E., and J. T. Zottola. 2017. “Thermosyphon Design for a Changing Arctic.” In Proceedings, 17th International Conference on Cold Regions Engineering, 10-13 September, Duluth, MN. https://doi.org/10.1061/9780784481011.015. 


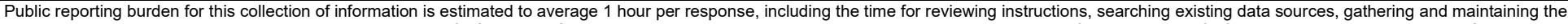

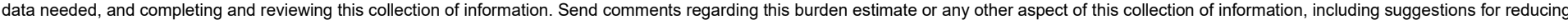

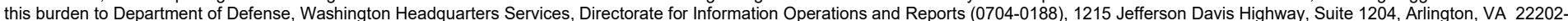

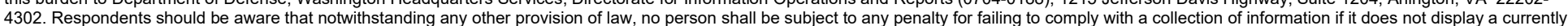

4302. Respondents should be aware that notwithstanding any other provision of law, no person shall
valid OMB control number. PLEASE DO NOT RETURN YOUR FORM TO THE ABOVE ADDRESS
1. REPORT DATE (DD-MM-YYYY)
October 2021
2. REPORT TYPE
Final Report

\title{
4. TITLE AND SUBTITLE
}

Artificial Ground Freezing Using Solar-Powered Thermosyphons

remer

ticing

(2)

(n)

\section{AUTHOR(S)}

Anna M. Wagner, Jon B. Maakestad, Edward Yarmak Jr., and Thomas A. Douglas
\end{abstract}

Arctic Foundations Inc. 5621 Arctic Boulevard Anchorage, AK 99518

3. DATES COVERED (From - To) FY18-FY20

\section{5a. CONTRACT NUMBER}

\section{5b. GRANT NUMBER}

\section{5c. PROGRAM ELEMENT}

0603734A/0603119A

5d. PROJECT NUMBER

$\mathrm{T}_{15} / \mathrm{BO}_{3}$

5e. TASK NUMBER

A1120/SB0321

5f. WORK UNIT NUMBER

\section{PERFORMING ORGANIZATION NAME(S) AND ADDRESS(ES)}

U.S. Army Engineer Research and Development Center (ERDC)

Cold Regions Research and Engineering Laboratory (CRREL)

4070 9th Street

Fort Wainwright, AK 99703

\section{SPONSORING / MONITORING AGENCY NAME(S) AND ADDRESS(ES)}

Headquarters, U.S. Army Corps of Engineers

Washington, DC 20314-1000

12. DISTRIBUTION / AVAILABILITY STATEMENT

Approved for public release; distribution is unlimited.

\section{SUPPLEMENTARY NOTES}

\section{ABSTRACT}

Thermosyphons are an artificial ground-freezing technique that has been used to stabilize permafrost since the 1960s. The largest engineered structure that uses thermosyphons to maintain frozen ground is the Trans Alaska Pipeline, and it has over 124,00o thermosyphons along its approximately $1300 \mathrm{~km}$ route. In passive mode, thermosyphons extract heat from the soil and transfer it to the environment when the air temperature is colder than the ground temperature. This passive technology can promote ground cooling during cold winter months.

To address the growing need for maintaining frozen ground as air temperatures increase, we investigated a solar-powered refrigeration unit that could operate a thermosyphon (nonpassive) during temperatures above freezing. Our tests showed that energy generated from the solar array can operate the refrigeration unit and activate the hybrid thermosyphon to artificially cool the soil when air temperatures are above freezing. This technology can be used to expand the application of thermosyphon technology to freeze ground or maintain permafrost, particularly in locations with limited access to line power.

\section{SUBJECT TERMS}

Artificial ground freezing, Climatic changes, Cold regions, Infrastructure, Permafrost--Stability, Refrigeration, Solar array, Thermosyphons, Warming climate

\section{SECURITY CLASSIFICATION OF:}

\section{a. REPORT}

Unclassified

\section{b. ABSTRACT}

Unclassified

\section{LIMITATION OF ABSTRACT}

c. THIS PAGE

Unclassified
SAR
18. NUMBER OF PAGES

33 19a. NAME OF RESPONSIBLE PERSON

19b. TELEPHONE NUMBER (include area code) 